\title{
Cultural Methods and Environmental Conditions Affecting Gray Mold and Its Management in Lisianthus
}

\author{
Lena Shpialter, Dalia Rav David, Irit Dori, Uri Yermiahu, Shimon Pivonia, Rahel Levite, and Yigal Elad
}

First, second, and seventh authors: Department of Plant Pathology and Weed Research, Agricultural Research Organization, The Volcani Center, Bet Dagan 50250, Israel; third author: R\&D South, M. P. 4, 85400, Israel; fourth author: ARO, Gilat Research Center, M. P. Negev 2, 85280, Israel; and fifth and sixth authors: Central and North Arava R\&D, Sapir, M. P. Arava 86825, Israel. Accepted for publication 29 December 2008.

\begin{abstract}
Shpialter, L., Rav David, D., Dori, I., Yermiahu, U., Pivonia, S., Levite, R., and Elad, Y. 2009. Cultural methods and environmental conditions affecting gray mold and its management in lisianthus. Phytopathology 99:557-570.

Gray mold, caused by Botrytis cinerea, severely affects the base of the stems of lisianthus (Eustoma grandiflorum) plants as well as the cut stems left after flowers are harvested. This study examined infection of lisianthus plants by $B$. cinerea under laboratory and commercial greenhouse production conditions typical for Israel and evaluated cultural methods for manipulating disease development in commercial greenhouses. Although the lower nodes of lisianthus stems are typically infected, in this study, the inherent susceptibility of these nodes was less than that of nodes midway up the stem. Greater light intensity (4,860 lux) was associated with significantly more severe stem wounds than lower

of gray mold along leaves toward the stem was slower at $26^{\circ} \mathrm{C}$ than at 18 to $20^{\circ} \mathrm{C}$ and was fastest at relative humidity (RH) levels close to saturation $(>99 \%)$. B. cinerea infection developed in all stem wounds exposed to 65 to $99 \% \mathrm{RH}$ and at temperatures of 12 to $29^{\circ} \mathrm{C}$. Infection severity in stem wounds (measured as lesion length) on whole plants was significantly less at $26^{\circ} \mathrm{C}$ than at 18 or $22^{\circ} \mathrm{C}$, and was significantly higher at $99 \% \mathrm{RH}$ compared with 70 to 85 and 85 to $95 \% \mathrm{RH}$. Severity of gray mold was the greatest at 15 to $22^{\circ} \mathrm{C}$ and 85 to $99 \% \mathrm{RH}$. Under commercial greenhouse conditions, supplemental calcium $\left(\mathrm{Ca}\left(\mathrm{NO}_{3}\right)_{2}\right)$ applied in fertigation or as a spray led to moderate yet significant reduction in disease severity. In addition, polyethylene soil cover and the use of buried drip irrigation instead of surface drip irrigation suppressed gray mold significantly on cut stems following harvest. Covering the soil with polyethylene also suppressed gray mold significantly as compared with the common practice of growing lisianthus in bare soil.
\end{abstract} light intensities of 140 to 1,020 lux. Lower light intensity (140 lux) was associated with significantly more severe leaf infection. The development

Lisianthus (Eustoma grandiflorum Grise.) is grown for cut flowers and potted plants. Cut flower lisianthus crops are grown in southern Israel for export during the winter. Botrytis cinerea causes gray mold on lisianthus flowers $(48,50)$ and stem bases (49), but no research reports on the etiology and management of this disease in this crop are currently available. Lisianthus is planted from the end of August to mid-October in Israel and the crop grows as single-stem plants to form a dense canopy. The first stem (flower) harvest occurs during the winter (December to January). Five centimeters of the lower stem is left after harvest, from which a few side branches grow to develop the flowers for the second harvest period (March to June). This secondary growth interferes with aeration of the crop. Stem gray mold becomes a severe problem in the dense lisianthus crops grown in Israel, especially in unheated greenhouses, where the disease commonly causes the death of 10 to $25 \%$ of the plants. In Israeli greenhouses, the disease can cause up to $50 \%$ mortality (Y. Elad, personal information). The research described here focused on lisianthus stem infections caused by $B$. cinerea .

$B$. cinerea infects many vegetable, ornamental, and horticultural crops $(16,17)$. Stem infection (as opposed to leaf infection) by $B$. cinerea is a problem in several greenhouse crops $(17,19$, $35,37)$. Studies on various crops have yielded a wide range of information regarding the conditions that promote $B$. cinerea infection in greenhouse crops (8). The temperature range for gray

Corresponding author: Y. Elad; E-mail address: elady@ volcani.agri.gov.il

doi:10.1094/PHYTO-99-5-0557

(c) 2009 The American Phytopathological Society
Additional keywords: calcium nitrate, mulch, stem infection, subirrigation.

mold development in greenhouse crops is 12 to $30^{\circ} \mathrm{C}$ (30) with an optimal range of 15 to $20^{\circ} \mathrm{C}$, although the pathogen is active even at temperatures as low as $0^{\circ} \mathrm{C}(9)$. Initial infection occurs on live or dead parts of plants (30).

Heating the greenhouse results in lower levels of gray mold in vegetable, flower, and ornamental crops $(25,35)$. Moreover, increasing the temperature in heated greenhouses resulted in reduced stem infections on tomato (10), but gray mold development along tomato stems was shown to be highest at $30^{\circ} \mathrm{C}(38)$. Nevertheless, current energy costs deter farmers in Israel from using intensive heating (Y. Elad, personal information). Aeration and air circulation may reduce gray mold by reducing the amount of time that a water film is present on susceptible plant parts (15). Cultural methods, such as reduced planting density and reduction of canopy density, can help reduce gray mold development (31, 44). Reducing air humidity by covering the soil has also been suggested as a means to restrict gray mold development $(12,15)$. This practice also affects other humidity-promoted diseases, such as tomato late blight (5). Gray mold develops at relative humidity (RH) levels $>90 \%$, and conidial germination occurs in water (30), but the disease has been shown to develop under lower RH conditions on tomato and sweet basil stem wounds. In these crops, optimal disease development was observed at 75 to $85 \%$ RH $(34,36)$. Such unusual examples of $B$. cinerea infection at lower $\mathrm{RH}$ occur because moisture on the wound surface, which originates from within the plant, is sufficient to promote infections that, at a later stage, develop inside the host tissue $(10,35)$.

The susceptibility of plant tissues to $B$. cinerea may change as the tissues mature. Young geranium flowers were shown to be less susceptible to $B$. cinerea infection than older flowers, and younger 
(4 weeks old) geranium leaves were shown to be less susceptible than older leaves ( 8 to 10 weeks old) (40). Moreover, plant physiology, as affected by plant nutrition, can also affect susceptibility to $B$. cinerea infection $(18,27,46)$. In some cases, calcium (Ca) fertilization and the presence of high concentrations of $\mathrm{Ca}$ in the plant tissues have been shown to effectively reduce gray mold severity $(2,4,47,51)$. Several possible mechanisms for disease reduction due to high levels of $\mathrm{Ca}$ in plant tissues have been suggested, including a reduction in ethylene emission by the plant, a decrease in susceptibility of plant membranes, and, especially, pectin constituents to pathogen hydrolytic enzymes and inhibition of leakage of nutrients to the plant surfaces (13). However, the transport of $\mathrm{Ca}$ ions to some plant organs may be limited, because this element is transported in the evapotranspiration flow and secondary movement of $\mathrm{Ca}$ does not occur in plants $(1,2,51)$.

The objective of the present work was to examine factors that influence $B$. cinerea infection of lisianthus stems under greenhouse conditions typical of Israel. We wanted to identify strategies that could be used to manipulate growth conditions within commercial greenhouses to slow progress of the disease and reduce the need for chemical control measures.

\section{MATERIALS AND METHODS}

Laboratory experiments. Incidence and severity of disease were evaluated in a series of laboratory experiments. In these experiments, the effects of lisianthus cultivar, temperature, $\mathrm{RH}$, stem wounding method, inoculation method, and light intensity on gray mold on detached leaves, excised stem segments, and whole lisianthus plants were evaluated. The effects of wounding method and inoculation method were evaluated using excised stem segments and in whole plants. The effect of a plastic barrier on the soil surface was evaluated in whole plants.

Host plants. Lisianthus plants of cvs. Echo Champagne and Yellow Catalina were obtained from a commercial nursery (Hishtil, Ashkelon, Israel) 40 to 50 days after seeding and transplanted into 1-liter pots containing a peat/volcanic gravel (3:7, vol/vol) growth mixture. Echo Champagne was used in all experiments. In the cultivar experiment, Echo Champagne and Yellow Catalina were both used. The plants were irrigated using drench irrigation every 1 to 3 days, allowing for $30 \%$ drainage. One week after the plants were transplanted, they were fertilized with 20:20:20 N: $\mathrm{P}_{2} \mathrm{O}_{5}: \mathrm{K}_{2} \mathrm{O}$ fertilizer at $5 \mathrm{~g} /$ liter. An aliquot of 250 $\mathrm{ml}$ of this solution was applied to each pot each time the plants were irrigated. The plants were maintained at 20 to $25^{\circ} \mathrm{C}$ in a pest-free, disease-free greenhouse for 2 to 3 weeks prior to initiation of the experiments. The experiments were initiated when the plants had reached the five-node developmental stage.

Pathogen and disease. B. cinerea (isolate BcI16) (43) was cultured on potato dextrose agar (PDA) (Difco Laboratories, Detroit) in petri dishes incubated at $20^{\circ} \mathrm{C}$. Conidia were harvested from 10 - to 14-day-old cultures by agitating $1 \mathrm{~cm}^{2}$ of agar bearing mycelia and conidia in a glass tube with tap water. The suspension was then filtered through cheesecloth. The concentration of conidia was determined using a hemacytometer and a light microscope, and adjusted to $5 \times 10^{5}$ cells $/ \mathrm{ml}$. Because $B$. cinerea conidia need carbon and phosphate for germination and penetration (6), $0.1 \%$ glucose was added to the final conidial suspension together with $0.1 \% \quad \mathrm{KH}_{2} \mathrm{PO}_{4}$. These supplements have been shown to facilitate germination of $B$. cinerea conidia and subsequent leaf infection (14).

Leaf assays. Detached and attached leaves were examined. Detached leaves were inoculated immediately after harvest and kept in a humidity chamber at $20 \pm 1^{\circ} \mathrm{C}, 97 \pm 3 \% \mathrm{RH}$, and 1,020 lux light intensity unless otherwise mentioned. Twenty detached leaves were used for each replication of each treatment. For the studies involving attached leaves, five leaves/plant from at least five plants were each inoculated with a $10-\mu$ ldrop of a $5 \times 10^{5}$ conidia/ml suspension and incubated under the conditions described above. The severity of the resulting necrotic lesion on each leaf was determined according to the scale described below. The diameter of a $10-\mu \mathrm{l}$ drop of inoculum on a leaf was $\approx 3 \mathrm{~mm}$, which corresponded to an area of $7 \mathrm{~mm}^{2}$. Disease developed gradually and was first visible between 3 and 5 days after inoculation. Initially, each infection was observed as a small necrotic lesion covering only part of the area originally covered by the drop of $B$. cinerea conidial suspension. The diameter of a $B$. cinerea lesion on a typical lisianthus leaf 9 to 10 days after inoculation was $\approx 9 \mathrm{~mm}$, which corresponded to an area of $63.5 \mathrm{~mm}^{2}$. A 12-mm-diameter lesion (corresponding to an area of $113 \mathrm{~mm}^{2}$ ) was used as a base size and assigned a value of $100 \%$, because this was the maximum lesion size observed. A pictorial scale of lesion sizes was used for evaluating the observed disease, including the following relative sizes: $0,1,2,5,10,20,40,75$, and $100 \%$ of a $12-\mathrm{mm}$-diameter lesion. Lesion size (a measure of disease severity) was determined for each lesion using this pictorial scale $(21,22,43)$. In commercial fields, leaf infections may lead to stem base infections. With this in mind, we tested the conditions that promote the development of rot lesions along leaves and toward the stems by applying inoculum in the center of attached leaves and then monitoring the distance between the lesion edge and the stem.

Stem assays. Stem wound infection was evaluated on stem pieces $(5 \mathrm{~cm}$ each) and on wounds created on whole plants growing in pots. A suspension of $B$. cinerea conidia was prepared as described above. Stem pieces were cut from nodes 2 and 3 (where node 0 is the node immediately above the stem base) and placed in wet perlite that covered the lower $1 \mathrm{~cm}$ of the section. All stem segments were placed in $10-\mathrm{cm}$-diameter pots, with 10 pieces/pot. Pots were arranged randomly in polyethylene-covered boxes (20 by 15 by $30 \mathrm{~cm}$ ), in which environmental conditions were maintained as described below. Each wound (see below for description of the wounding process) was inoculated with a 10- $\mu$ l drop of conidial suspension as described above, unless another source of inoculum was used as described below. Detached stem pieces were inoculated immediately after harvest and kept in a growth chamber at $20 \pm 1{ }^{\circ} \mathrm{C}, 97 \pm 3 \% \mathrm{RH}$, and 1,020 lux light intensity, unless otherwise mentioned. Wounded whole plants were incubated under the same conditions. Disease severity was monitored by measuring the length of the lesion that developed at each inoculated wound (37).

Effect of inoculation method on stem infection. In an attempt to further investigate the infection of lisianthus stem wounds by $B$. cinerea, three different inoculation methods were tested in addition to the conidial suspension method described above. The additional inoculation methods involved placing a mycelial plug ( $3 \mathrm{~mm}$ in diameter) taken from the edge of a 4-day-old $B$. cinerea culture (on PDA) onto the wound surface; dry brushing conidia from a 14-day-old conidiating $B$. cinerea culture (on PDA) onto the wound with a paint brush; and blowing air (dry blowing) over a 14-day-old conidiating $B$. cinerea culture (on PDA) toward the wound. The number of conidia on the wound surface was counted on a sample of test stems that were washed with water containing $0.01 \%$ Tween 80 , and the concentration of conidia was then determined using a hemacytometer and a light microscope. The dry brushing and dry blowing methods resulted in inoculation rates of $1 \times 10^{3}$ to $7 \times 10^{3}$ and $3 \times 10^{3}$ to $6 \times 10^{3}$ conidia/wound, respectively, compared with an inoculation rate of $3 \times 10^{3}$ to $5 \times 10^{3}$ conidia/wound for the conidial suspension method.

Effect of wounding method. In order to test the effect of the nature of the cut on infection and disease development, stem pieces were excised from nodes 2 to 4 . Stem wounds were created by cutting horizontally through the entire stem with pruning shears, except for one set of experiments in which some stems were cut diagonally, at a $45^{\circ}$ angle, in order to test the effect of wound type on gray mold disease. Intensity of conidiation was 
evaluated on scale of 0 to 100 , corresponding to 0 to $100 \%$ coverage of the symptomatic area by $B$. cinerea conidiophores and conidia.

Effects of light intensity, temperature, and RH. After inoculation, the effects of temperature, $\mathrm{RH}$, and light intensity on disease severity were evaluated. In each experiment, plant material for the control treatment was kept at $20 \pm 1{ }^{\circ} \mathrm{C}, 97 \pm 3 \% \mathrm{RH}$, and 1,020 lux light intensity. It was suspected that the relatively high level of gray mold infection at the base of lisianthus stems might reflect the difference in light intensity in the lower canopy versus the upper canopy. In experiments involving light-intensity treatments, the light intensity was modified to $140,1,020$, and 4,860 lux using fluorescent and condescend lamps. Light intensity was measured using a YF-1065 Digital Lux Tester (Yu Fing, Taiwan). The effect of light intensity on infection was tested in two cultivars that show different levels of disease in commercial fields. Cv. Echo Champagne is regarded by Israeli field workers as being more susceptible under commercial conditions (higher disease levels) than cv. Yellow Catalina (Y. Messika, personal communication). Stems of lisianthus are usually infected at the lower nodes (Y. Elad, personal information). We tested the effect of node height on the susceptibilities of excised nodes and wounds on whole plants to infection by $B$. cinerea.

In experiments involving temperature treatments, temperatures of $12,15,18,22,25$, and $29^{\circ} \mathrm{C}$ were used for the experiments involving stem pieces; 18,22 , and $26^{\circ} \mathrm{C}$ for the experiments involving detached leaves; and 18,22 , and $26^{\circ} \mathrm{C}$ for the experiments involving potted plants. $\mathrm{RH}$ levels were manipulated in the boxes by placing stem pieces above saturated salt solutions of $\mathrm{NH}_{4} \mathrm{NO}_{3}$ (65\% RH), $\mathrm{NaCl}(75 \% \mathrm{RH}), \mathrm{KCl}(85 \% \mathrm{RH}), \mathrm{KNO}_{3}(94 \% \mathrm{RH})$, $\mathrm{K}_{2} \mathrm{SO}_{4}(97 \% \mathrm{RH})$, and no salt $(99 \% \mathrm{RH})$ (52). Detached leaves were incubated in boxes covered with perforated polyethylene. Each hole was $1 \mathrm{~cm}$ long and hole densities of 0 to 8 holes $/ \mathrm{dm}$ were used to produce RH levels of 91 to 94,95 to 96,97 to 99 , and $>99 \%$ as recorded by data loggers (Hobo, Onset Computer Corp., Pocasset, MA). Potted plants were incubated at RH levels of 70 to 85,85 to 95 , and $>99 \%$ RH.

In one set of experiments, a 0.15 -mm-thick piece of transparent polyethylene $(7$ by $7 \mathrm{~cm}$ ) was placed in each one-plant pot between the soil and the lower lisianthus leaves, and disease development on the leaves was evaluated following inoculation. In another set of experiments with potted lisianthus plants, the effect of a calcium solution $\left(\mathrm{Ca}\left(\mathrm{NO}_{3}\right)_{2}, 0.1 \mathrm{~g} / \mathrm{ml}\right)$ on infection and conidiation was tested either after spraying $(10 \mathrm{ml} / \mathrm{plant})$ or drenching (100 ml/plant). Lisianthus pots were maintained at 20 to $25^{\circ} \mathrm{C}$ in an experimental greenhouse.

Greenhouse experiments. Two experiments were performed in walk-in tunnel greenhouses and one experiment was performed in a greenhouse at the Besor Research Station of R\&D South, located in the northwestern part of the Negev Desert (southern Israel). In the first study (2004-05 growing season), the effects of polyethylene soil cover $(0.04 \mathrm{~mm}$ thick, colored silver on the upper side and black on the side facing the soil; Ginegar Plastic Products Ltd., Kibbutz Ginegar, Israel) and irrigation method on the incidence of gray mold of lisianthus were evaluated. In the second study (2005-06 growing season), the effects of polyethylene soil cover and several methods of applying supplemental $\mathrm{Ca}$ on the incidence and severity of gray mold on lisianthus were evaluated. In the third experiment (2006-07), the effect of calcium nitrate on lisianthus gray mold was evaluated. A fourth experiment was carried out in walk-in tunnel greenhouses at the Yair Research Station of Central and North Arava R\&D. In this study (2006-07 growing season), the effect of irrigation method on the incidence of gray mold of lisianthus was evaluated.

Plant and pathogen material. Lisianthus cv. Echo Champagne was planted in sandy soil at the Besor R\&D Research Station on 13 October 2004, 12 September 2005, and 15 September 2006 for the first to third greenhouse experiments, respectively. Each year, experiments were conducted in eight walk-in tunnel greenhouses, each of which was covered with ultraviolet-absorbing, 0.15-mmthick polyethylene (Ginegar Plastic Products Ltd.). Each greenhouse had a ground area of $60 \mathrm{~m}^{2}$ and included three 1-m-wide beds. Six rows of lisianthus were planted in each bed for a density of 60 plants $/ \mathrm{m}^{2}$. In the third year, the experiment was carried out in a $0.15-\mathrm{mm}$-thick polyethylene covered, $250-\mathrm{m}^{2}$ greenhouse. Plants were planted in 1-m-wide beds. Three-meter-long beds were allocated to each plot and treatments were arranged in random block design. The plants consisted of one stem until the first harvest and were drip irrigated and fertilized (80:13.5:103 $\mathrm{N}: \mathrm{P}: \mathrm{K})$ using a $17-\mathrm{mm}$-diameter polyethylene pipe with 1.6 -liter/h drippers placed every $20 \mathrm{~cm}$ (Netafim, Kibbutz Hatzerim, Israel). The plants were maintained according to local, commercial standards. In order to ensure even distribution of $B$. cinerea inoculum in the greenhouses, nine pots of 2-month-old tomato plants with gray mold lesions bearing conidiophores and conidia of $B$. cinerea were placed in each greenhouse 75 days after planting. The infected tomato plants were placed in each bed, one plant on the border between every second plot and evenly scattered around the greenhouse. Conidia spread naturally in the greenhouse. No fungicides were applied against gray mold during the trials. In the first experiment, stem base infections of only whole plants by $B$. cinerea were monitored whereas, in the second and third greenhouse experiments, both cut stems and whole plants were monitored for infection. Every 3 weeks, all diseased plants were uprooted, examined for the presence of gray mold, counted, and removed from the greenhouse.

Lisianthus cv. Echo White was planted in sandy soil at the Yair (Central and North Arava R\&D) Research Station on 5 October 2006 for the fourth greenhouse experiment. The experiment was conducted in four 7-by-6.5 walk-in tunnel greenhouses, each of which was covered with ultraviolet-absorbing, 0.15-mm-thick polyethylene (Ginegar Plastic Products Ltd). Each greenhouse included three $1.5-\mathrm{m}$-wide beds. Six rows of lisianthus were planted in each bed for a density of 60 plants $/ \mathrm{m}^{2}$. Beds $(6.5 \mathrm{~m}$ long) were allocated to each plot and treatments were arranged in a random block design so that there was one replicate of each treatment in each greenhouse. Four 1-m-long subplots were set up for disease and yield sampling.

Effect of polyethylene soil cover. Two methods, a polyethylene soil cover and a sub-irrigation system, were used to manipulate the humidity in the greenhouse and thereby affect the infection of plants by $B$. cinerea. The soil of each greenhouse was either left uncovered or covered with silver/black polyethylene (Ginegar Plastic Products Ltd.) as a main treatment in four replicates. Irrigation was carried out using a drip system. In the covered plots, the drippers were placed underneath the polyethylene. There were three replicates of each split-plot irrigation treatment in each greenhouse, for a total of 12 replicates per treatment.

Effect of irrigation method. The split-plot treatments in the first tunnel experiment at the Besor Station involved a drip-irrigation system that was placed $20 \mathrm{~cm}$ below the soil surface and was operated beginning 45 days after planting, at which point the above-mentioned drip irrigation was discontinued. The drip-irrigation system consisted of 17-mm-diameter polyethylene pipe with 1.6-liter/h drippers placed every $20 \mathrm{~cm}$ (Netafim). In the control plots, the initial drip-irrigation system (drippers placed at the soil surface) was operated throughout the growing season. Disease incidence was monitored from 7 March through 29 June 2005.

The treatments in the fourth tunnel experiment, located at the Yair Station, involved a drip-irrigation system that was placed $20 \mathrm{~cm}$ below the soil surface and was operated beginning 59 days after planting. One week after this system was turned on, the aboveground drip irrigation was discontinued. The drip-irrigation system consisted of 17-mm-diameter polyethylene pipe with 
1.6-liter/h drippers placed every $20 \mathrm{~cm}$ (Netafim). In the control plots, the initial drip-irrigation system (drippers placed at the soil surface) was operated throughout the growing season. Two $B$. cinerea inoculum plants were placed in each greenhouse 85 days after planting. Crop maintenance and disease sampling were carried out as described above. Disease incidence was evaluated on 25 April 2006. Results of this experiment are described after the results of the first Besor Research Station experiment.

Effects of applications of supplemental calcium. The $\mathrm{Ca}$ treatments in the second tunnel experiment included fertigation, spraying with a backpack, air-assisted sprayer with $2 \% \mathrm{Ca}\left(\mathrm{NO}_{3}\right)_{2}$, both $\mathrm{Ca}$ treatments applied in combination, or no $\mathrm{Ca}$ treatment (control). Each treatment was applied in eight replicates. The basic fertigation treatment consisted of tap water (containing $\mathrm{Ca}^{2+}$ at $70 \mu \mathrm{g} / \mathrm{g}), \mathrm{Ca}\left(\mathrm{NO}_{3}\right)_{2}(0 \mu \mathrm{g} / \mathrm{g}), \mathrm{NH}_{4} \mathrm{NO}_{3}(170 \mu \mathrm{g} / \mathrm{g}), \mathrm{H}_{3} \mathrm{PO}_{4}(30$ $\mu \mathrm{g} / \mathrm{g}), \mathrm{KNO}_{3}(270 \mu \mathrm{g} / \mathrm{g}),\left(\mathrm{NH}_{4}\right)_{2} \mathrm{SO}_{4}(0 \mu \mathrm{g} / \mathrm{g}), \mathrm{KCl}(0 \mu \mathrm{g} / \mathrm{g})$, and microelements EDTA chelates $(100 \mu \mathrm{g} / \mathrm{g})$. The $\mathrm{Ca}$ fertigation treatment consisted of $\mathrm{Ca}\left(\mathrm{NO}_{3}\right)_{2}(300 \mu \mathrm{g} / \mathrm{g}), \mathrm{NH}_{4} \mathrm{NO}_{3}(50 \mu \mathrm{g} / \mathrm{g})$, $\mathrm{H}_{3} \mathrm{PO}_{4}(30 \mu \mathrm{g} / \mathrm{g}), \mathrm{KNO}_{3}(150 \mu \mathrm{g} / \mathrm{g}),\left(\mathrm{NH}_{4}\right)_{2} \mathrm{SO}_{4}(70 \mu \mathrm{g} / \mathrm{g}), \mathrm{KCl}$ $(100 \mu \mathrm{g} / \mathrm{g})$, and EDTA chelates of microelements $(100 \mu \mathrm{g} / \mathrm{g})$. This resulted in $\mathrm{Ca}^{2+}$ at $70 \mu \mathrm{g} / \mathrm{g}$ and 80:13.5:103 N:P:K in the lowest $\mathrm{Ca}$ treatment (control), and $\mathrm{Ca}^{2+}$ at $110 \mu \mathrm{g} / \mathrm{g}$ and 79:13.5:99 $\mathrm{N}: \mathrm{P}: \mathrm{K}$ in the Ca-supplemented treatments. Gray mold was observed and monitored starting on 9 January 2006.

Leaves and stem pieces were sampled from the untreated and $\mathrm{Ca}$ fertigation plots and the mineral contents of these tissues were analyzed. In the first sample, taken on 1 February 2006, the fourth leaf below the flower was assayed. In the second sample, taken on 6 June 2006, lower and upper leaves and the lower part of the stem were assayed. Samples of 30 leaves at each level and 10- to $20-\mathrm{cm}$ stem pieces were taken from each experimental plot. Leaves were separated from stems, rinsed with distilled water, dried at $60^{\circ} \mathrm{C}$, and then ground and analyzed according to the

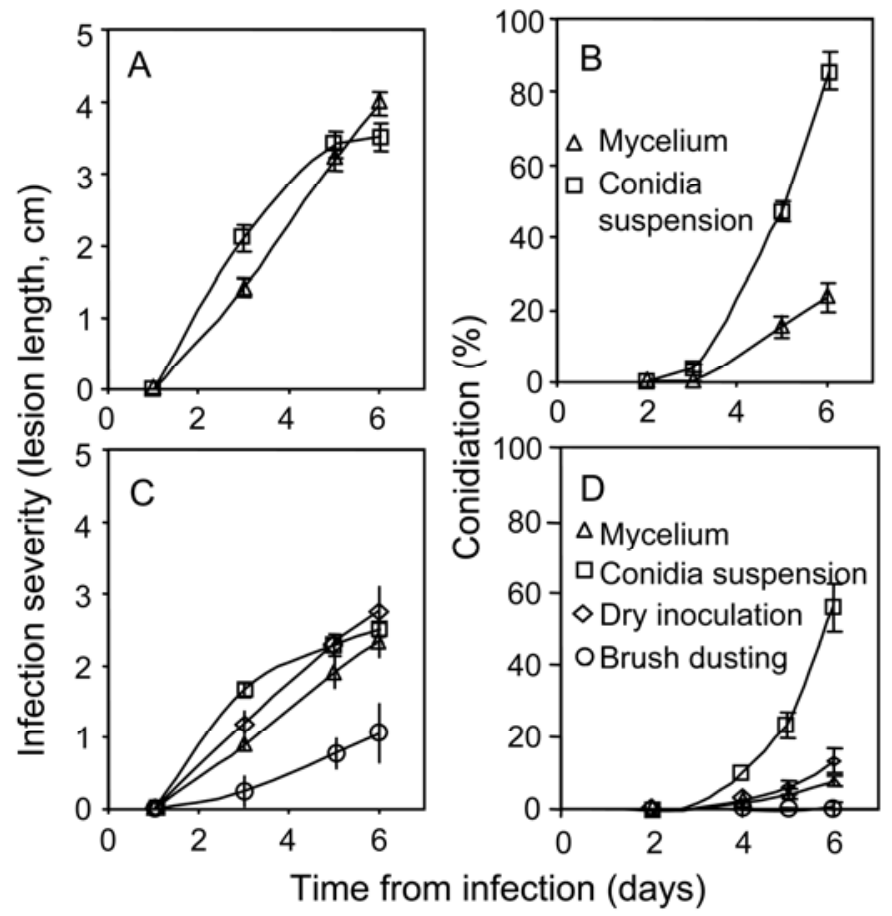

Fig. 1. Effect of Botrytis cinerea inoculum type and inoculation method on A and $\mathbf{C}$, severity of gray mold (expressed as length of lesion development along the stem) and $\mathbf{B}$ and $\mathbf{D}$, intensity of conidiation (expressed as percent of infected area covered by conidiophores and conidia) on $\mathbf{A}$ and $\mathbf{B}$, lisianthus pieces from nodes 2 and 3 and $\mathbf{C}$ and $\mathbf{D}$, stem cuts on whole plants. Excised stems were inoculated by placing mycelial plugs of $B$. cinerea on wounds or by inoculating the plant tissue with drops of an aqueous conidial suspension, or with dry conidia present in the air or dusted onto the wound. Bars represent the standard error of each mean. Each mean is an average of 10 replicates. protocol of Yermiahu et al. (51). Total N, P, and K contents of the leaves were determined after digestion with sulfuric acid and peroxide (41). The $\mathrm{N}$ and $\mathrm{P}$ concentrations were determined using an Autoanalyzer (Lachat Instruments, Milwaukee, WI), and $\mathrm{K}$ contents were analyzed with a flame photometer (Corning 400). $\mathrm{Ca}$ and $\mathrm{Mg}$ analysis was carried out after digestion with nitric acid and per chlorate, and the concentration of $\mathrm{Ca}$ was determined using an atomic absorption spectrophotometer (Perkin-Elmer 460).

Effect of calcium nitrate. The treatments in the third field experiment included spraying $2 \% \mathrm{Ca}\left(\mathrm{NO}_{3}\right)_{2}$ with a backpack airassisted sprayer, in comparison with a no-Ca treatment (control). There were five replicates for each treatment. $B$. cinerea inoculum-bearing plants were introduced into the greenhouses on 5 December 2005. Gray-mold-infected plants were observed 17 days after inoculation.

Microclimate measurements. Air temperature and $\mathrm{RH}$ were recorded hourly in the greenhouses using data loggers (Hobo, Onset Computer Corp.) positioned $10 \mathrm{~cm}$ above the ground. The duration (h) of temperature at $5{ }^{\circ} \mathrm{C}$ intervals and the duration of $\mathrm{RH}$ at $10 \%$ intervals were analyzed on a weekly basis. The presence of dew was estimated hourly using an electrical grid that served as an artificial leaf (WatchDog, Leaf Wetness/Temperature Logger; Spectrum Technologies, Inc., Plainfield, IL). The maximal resistance value obtained by the device is 14.9 mil-ohms and the dew estimation is described in relative units (U). Correlations between the above-mentioned microclimate parameters and the incidence of diseased plants during the growing season were calculated.

Statistical analysis. Controlled-condition experiments were carried out with 6 to 10 replicates/experiment and were repeated one to two times. Each greenhouse experiment had four replicates for the main treatment and 6 to 12 randomized replicates for the split-plot treatments. Area under disease progress curve (AUDPC) values were calculated. Data in percentages were arcsine transformed before further analysis. Disease severity and AUDPC data were analyzed using analysis of variance (ANOVA) and Fisher's protected least significant difference (LSD) test (42). Standard errors (SEs) of the treatment means were calculated and disease levels were separated statistically following a one-way ANOVA. The effect of polyethylene soil cover on disease severity in the growth chamber was evaluated using linear regression analysis (32). Linear regression analysis was also used to evaluate the relationships between disease incidence and temperature and $\mathrm{RH}$ data. Nonlinear regression analyses (32) were also carried out but did not result in better descriptions of the relationships between the examined parameters than those provided by linear regression. Pearson's correlation coefficients were calculated. Statistical analyses were performed using JMP software (SAS Institute, Cary, $\mathrm{NC})$.

\section{RESULTS}

Infection of stem pieces and stem wounds. Inoculating with conidial suspensions as opposed to mycelial plugs did not significantly affect infection of excised stem pieces (Fig. 1A). Infection developed significantly more slowly when conidia were brushed onto the wounds (Fig. 1C). In the experiments with excised stem pieces and wounds inflicted on the stems of whole plants, conidiophore formation was significantly slower when mycelial inoculum was used than when a conidial suspension was applied (Fig. 1B and D). Differences between inoculation methods were larger when conidiation was evaluated than when disease severity was evaluated, indicating faster gray mold development following inoculation with the conidial suspension than with mycelial and dry inoculations (Fig. 1B and D). No gray mold was observed on uninoculated wounds.

The suspension of $5 \times 10^{5}$ conidia/ml supplemented with $0.1 \%$ glucose and potassium phosphate resulted in lesions with an 
average length of $3.7 \pm 0.3 \mathrm{~cm}$ after 6 days and was found to be significantly superior $(P \leq 0.05)$ for infecting stem wounds, as compared with similar suspensions supplemented with $0,0.01$, and $0.05 \%$ glucose and potassium phosphate, which resulted in lesions that were $0.2 \pm 0.03,0.9 \pm 0.07$, and $2.1 \pm 0.2 \mathrm{~cm}$ in length, respectively. It was superior also to infection caused by the application of suspensions of $10^{3}$ to $10^{4}$ conidia $/ \mathrm{ml}$ with glucose and phosphate at concentrations of 0 to $0.1 \%$ (data not shown).

Effects of plant node position and inoculum type on infection. Inoculation of horizontally cut stem wounds at nodes 0 to 5 with mycelial plugs colonized by $B$. cinerea resulted in lesions that were $0.50 \pm 0.03,1.23 \pm 0.22,1.23 \pm 0.24,1.50 \pm 0.20,1.34 \pm$ 0.18 , and $0 \mathrm{~cm}$ in length $( \pm \mathrm{SE})$, respectively. Infection was significantly more severe at nodes 2 to 4 than at the higher and lower nodes $(P=0.035$, according to Fisher's protected LSD test; each mean is an average of 10 replicates).

When stem pieces that were excised from nodes 0 to 5 were inoculated with conidia (Fig. 2A and B), infection severity (expressed as AUDPC; centimeters by days through 7 days after

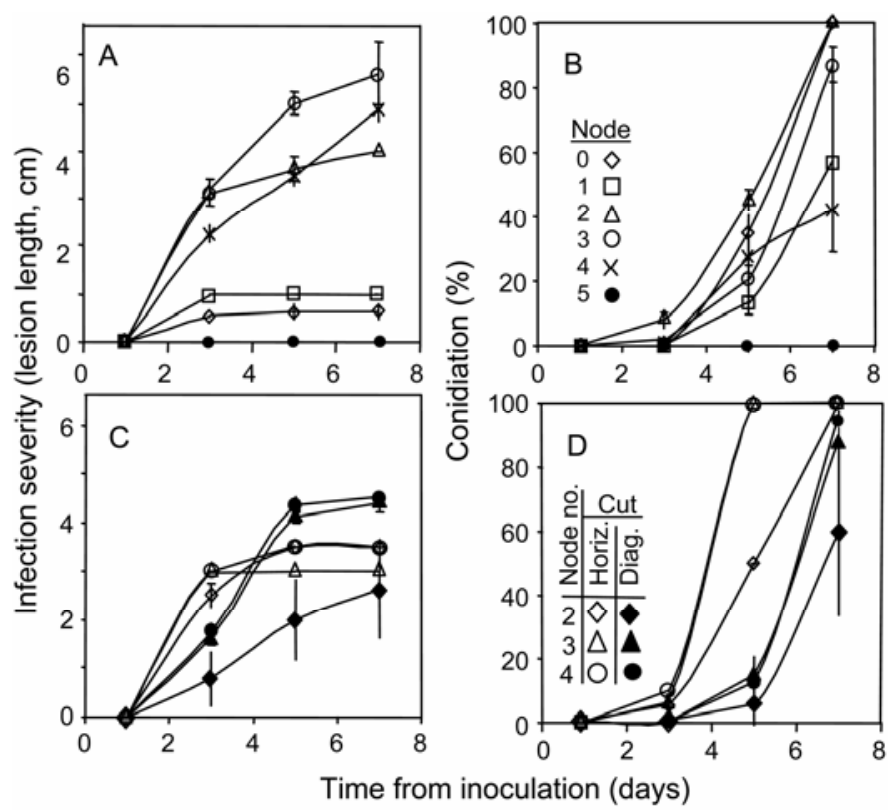

Fig. 2. Effect of node position and wound direction (horizontal or diagonal) on $\mathbf{A}$ and $\mathbf{C}$, severity of gray mold (expressed as length of the stem lesion) and B and D, intensity of conidiation (expressed as percent of infected stem covered by conidiophores and conidia) on lisianthus nodes. Stem pieces were excised by $\mathbf{A}$ and $\mathbf{B}$, a horizontal cut from nodes $1-6$ or $\mathbf{C}$ and $\mathbf{D}$, by a horizontal or diagonal cut from nodes $2-4$, and inoculated with conidia. Bars represent the standard error of each mean. Each mean is an average of six replicates. inoculation) was 2.9 (d), 5.0 (c), 17.5 (b), 21.9 (a), 16.4 (b), and 0 (e), respectively (treatments followed by the same letter in parentheses are not significantly different according to Fisher's protected LSD test, $P<0.001,10$ replicates). The highest infection rate was observed at node 3 . Conidiation intensity (expressed as AUDPC; percent by days through 7 days after inoculation) was 82 (c), 98 (bc), 131 (b), 205 (a), 170 (a), and 0 (d) in stem pieces from nodes 0 to 5 , respectively (treatments followed by the same letter in parentheses are not significantly different according to Fisher's protected LSD test, $P<0.0001)$. Thus, high levels of conidiation were observed on nodes 3 to 4 .

Effect of wounding method. In general, the direction of the cut did not affect the severity of disease or conidiation (Table 1) but less severe infections and less conidiation were observed on the diagonally cut stem pieces from node 2 compared with the horizontally cut pieces of all tested nodes (Fig. 2C and D; Table 1).

Effects of light intensity and lisianthus cultivar on infection of stem pieces and leaves. Under the controlled conditions examined in this experiment, significantly fewer stem infections (Table 2) and more severe leaf infections were observed on Echo Champagne than on Yellow Catalina (Table 2). Additionally, lower light intensity was associated with significantly lower levels of disease severity and less conidiation on stem pieces than higher light intensity (Table 2). In contrast, disease severity on leaves was significantly higher under higher light intensity (Table 2).

Development of disease in leaves. The development of infection along the leaves toward the stem was significantly slower at $26^{\circ} \mathrm{C}$ than at 18 to $20^{\circ} \mathrm{C}$. Infection development was faster at higher $\mathrm{RH}$, in the range of 91 to $>99 \%$, than at lower RHs. Infection developed more slowly on leaves from the lower nodes than those growing from the upper nodes (Fig. 3; Table 3).

Effects of temperature and RH on gray mold development on stem cuts. Horizontal stem cuts exposed to 65 to $99 \%$ RH and 12 to $29^{\circ} \mathrm{C}$ always developed $B$. cinerea infections following inoculation (Fig. 4; Table 4). Conidiation was never observed at $29^{\circ} \mathrm{C}$ and 65 to $94 \%$ RH (Table 4). Significantly higher levels of gray mold were observed at 15 to $25^{\circ} \mathrm{C}$ and $>75 \% \mathrm{RH}$ than at $65 \% \mathrm{RH}$ (Fig. 4; Table 4). The temperature range was 18 to $25^{\circ} \mathrm{C}$ at 65 to $75 \% \mathrm{RH}$ (Table 4). Significantly higher levels of conidiation were observed at $\geq 85 \% \mathrm{RH}$ (Table 4 ). Conidiation was high at 15 to $22^{\circ} \mathrm{C}$ but the temperature range for high levels of conidiation was 18 to $22^{\circ} \mathrm{C}$ at 85 and $99 \% \mathrm{RH}$ (Table 4).

Effects of temperature and RH on development of gray mold on stem wounds. Development of $B$. cinerea on stem wounds was studied at temperatures of 18 to $26^{\circ} \mathrm{C}$ and $\mathrm{RH}$ levels of 70 to $99 \%$. The disease developed more slowly on stem wounds of growing plants (Fig. 5; Table 5) than on stem pieces (Fig. 4; Table 4). Infection severity was least at $26^{\circ} \mathrm{C}$, highest at $22^{\circ} \mathrm{C}$, least at 70 to 85 and 85 to $95 \% \mathrm{RH}$, and highest at $99 \% \mathrm{RH}$ (Fig. 5; Table 5). Conidiation was observed only at $>99 \% \mathrm{RH}$ (Table 5). The rate of symptom development was significantly

TABLE 1. Effects of node position and type of wound on severity of gray mold on excised lisianthus stems ${ }^{\mathrm{y}}$

\begin{tabular}{|c|c|c|c|c|c|c|c|c|c|}
\hline \multirow[b]{2}{*}{ Wound direction } & \multirow[b]{2}{*}{ Node no. } & \multicolumn{4}{|c|}{ Infection severity } & \multicolumn{4}{|c|}{ Conidiation } \\
\hline & & AUDPC & Type of cut & Node no. & Cut-node & AUDPC & Type of cut & Node no. & Wound-node \\
\hline \multirow[t]{3}{*}{ Horizontal } & 2 & $15.5 \pm 0.5 \mathrm{a}$ & Horizontal a & $2 b$ & ns & $211 \pm 6.0 \mathrm{~b}$ & Horizontal a & $2 \mathrm{~b}$ & ns \\
\hline & 3 & $15.9 \pm 0.0 \mathrm{a}$ & $\ldots$ & & $\ldots$ & $320 \pm 0.0 \mathrm{a}$ & & $3 \mathrm{a}$ & $\ldots$ \\
\hline & 4 & $15.0 \pm 0.0 \mathrm{a}$ & $\ldots$ & & $\ldots$ & $315 \pm 5.2 \mathrm{a}$ & & $4 \mathrm{a}$ & $\ldots$ \\
\hline \multirow[t]{3}{*}{ Diagonal } & 2 & $8.2 \pm 0.6 b$ & Diagonal a & $3 \mathrm{a}$ & $\ldots$ & $70 \pm 11.4 \mathrm{~d}$ & Diagonal b & & $\ldots$ \\
\hline & 3 & $16.5 \pm 0.3 \mathrm{a}$ & $\ldots$ & & $\ldots$ & $120 \pm 14.7 \mathrm{c}$ & & & $\ldots$ \\
\hline & 4 & $16.8 \pm 3.4 \mathrm{a}$ & $\ldots$ & $4 \mathrm{a}$ & $\ldots$ & $121 \pm 33.4 \mathrm{c}$ & & & \\
\hline$P$ values ${ }^{\mathrm{z}}$ & $\ldots$ & $\ldots$ & 0.0574 & 0.0041 & 0.053 & $\ldots$ & $<0.0001$ & $<0.0001$ & 0.0859 \\
\hline
\end{tabular}

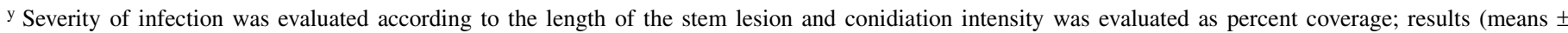
standard error) are presented as areas under disease progress curves (AUDPC; centimeters by days; $P<0.0011$ for infection severity and $P<0.001$ for conidiation) through 7 days after infection (Fig. 2C and D). Plants were incubated at $20 \pm 1{ }^{\circ} \mathrm{C}$, 1,020 lux, and $97 \pm 3 \%$ relative humidity. Treatments in each column followed by the same letter are not significantly different according to Fisher's protected least significant difference test; ns $=$ not significant.

${ }^{\mathrm{z}} P$ values for significance of major treatment factors and their combinations. 
lower at $26^{\circ} \mathrm{C}$. $\mathrm{RH}$ did not affect the rate at which lesions developed (Table 5).

Effect of polyethylene soil cover on development of gray mold on lower leaves. Leaf infection under controlled conditions was significantly different with bare soil (control) compared with infection in the polyethylene soil cover. Disease severity development was described by the formula $y=7.7 x-6.1\left(R^{2}=0.9822\right)$ and $y=10.8 \operatorname{Ln}(x)+0.3\left(R^{2}=0.9904\right)$ for the bare soil control and the polyethylene soil cover treatments. The AUDPC values for disease severity on leaves of the control plants and those in the polyethylene soil cover treatment plots were 147.6 and $78.8 \%$ by days, respectively; these values are significantly different $(P<$ 0.0001).

Sub-irrigation and polyethylene soil cover. Gray mold appeared during the development of the second crop of flowers (i.e., first observed 110 days after planting) in the 2004-05 experiment. The polyethylene soil cover and buried drip irrigation, individually and in combination, significantly suppressed gray mold on stems (Fig. 6; Table 6). For the second flower harvest, yield was highest in the combination treatment and lowest in the treatment in which the soil cover was used alone (Table 6). Flower quality, measured as flower length, flower weight, and the number of buds, was similar in all treatments. At the first and second flower harvests, the lengths of the flowers were 72 to 78 and 105 to $107 \mathrm{~cm}$, respectively; the numbers of buds on each plant were 7.5 to 9.0 and 9.2 to 10.7 for the two periods, respectively; and the flower weights were 118.0 to 120.5 and 96.2 to $121.3 \mathrm{~g} /$ flower, respectively. None of these parameters was significantly affected by the treatments.

Gray mold appeared during the development of the second crop of flowers (i.e., first observed 165 days after planting) in the 2006-07 experiment. The buried drip-irrigation and control treatments had 16.0 and $28.5 \%$ gray mold incidence, respectively $(P \leq$ $0.05)$. Flower total first yield in the buried drip-irrigation and control treatments were 58.6 and 46.5 flowers $/ \mathrm{m}^{2}$, respectively, significantly different from each other $(P \leq 0.05)$, whereas the number of A quality flowers was 45.1 and $36.5 / \mathrm{m}^{2}$, respectively, significantly not different from each other $(P \leq 0.05)$. Quality measures of the flowers in the respective treatments were as follows: length $=99.3$ and $106.9 \mathrm{~cm} /$ flower, weight $=34.7$ and $38.7 \mathrm{~cm} /$ flower, and number of buds $=5.0$ and 5.9/flower; in all quality parameters, the differences were insignificant $(P \leq 0.05)$.

Soil cover and calcium treatments. The rate of whole-plant stem infection by $B$. cinerea was low and reached two plants/plot 110 days after planting in the control plots. Whole-plant infection was reduced by the polyethylene soil cover (Table 7). Cut-stem infection was more pronounced than infection of whole plants and reached 18.5 stumps/plot in control plots at 110 days. Infection of cut stems was only significantly reduced by the polyethylene soil cover as a main factor in the ANOVAs (Fig. 7; Table 7). On bare soil, Ca sprays alone reduced gray mold significantly (Table 7).

Flower yield in the second greenhouse experiment was not significantly increased by any of the treatments (Table 7). The polyethylene cover soil had a negative effect on plant growth at the beginning of the season, reflected in lower yields for the plots with soil cover and no extra Ca treatment (Table 7); flower quality was statistically similar for all treatments (data not shown). There were no significant differences in flower quantity or quality in
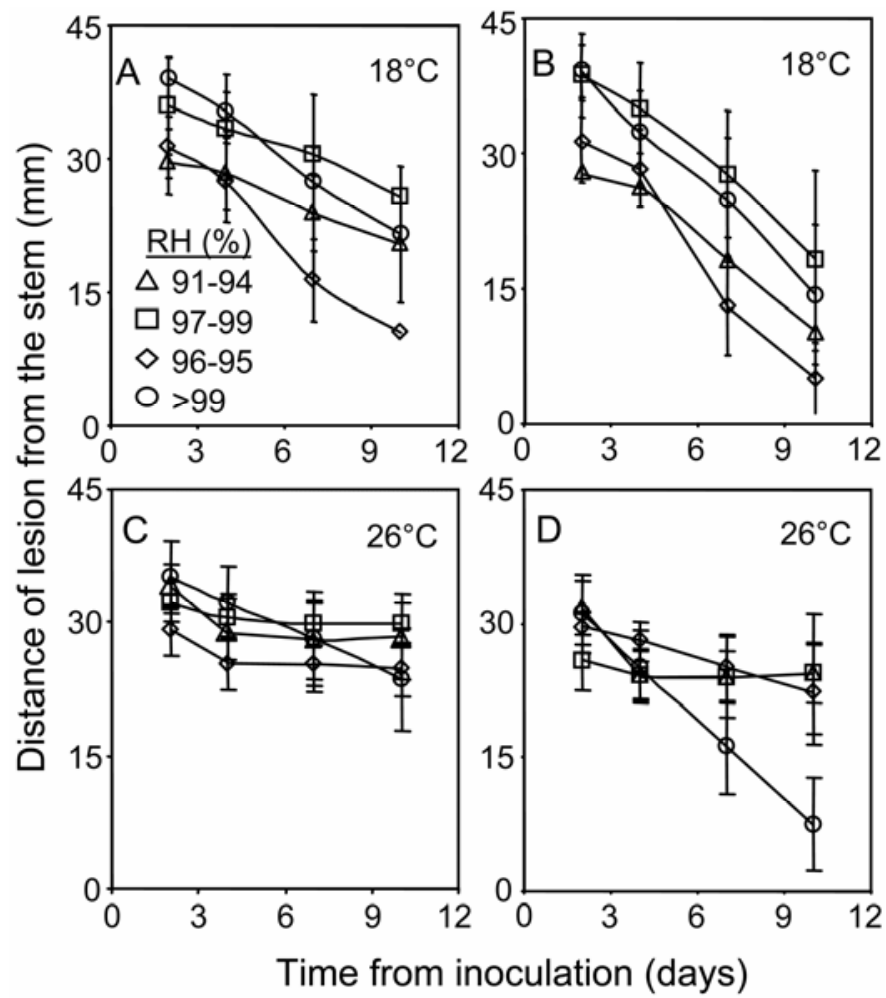

Fig. 3. Effects of temperature and relative humidity on the rate of development of Botrytis cinerea-incited gray mold along the $\mathbf{A}$ and $\mathbf{C}$, upper (node 5) and B and D, lower (node 0) leaves of lisianthus plants, expressed as the distance between the leaf lesion and the stem. Bars represent the standard error of each mean. Each mean is an average of 10 replicates.

TABLE 2. Effects of light intensity (LI) on the severity of gray mold on excised stem pieces of two lisianthus cultivars ${ }^{\mathrm{x}}$

\begin{tabular}{|c|c|c|c|c|c|c|c|c|c|c|c|c|}
\hline \multirow[b]{3}{*}{$\mathrm{Cv} .{ }^{\mathrm{y}}$} & \multicolumn{6}{|c|}{ Infection severity } & \multicolumn{6}{|c|}{ Conidiation } \\
\hline & \multicolumn{3}{|c|}{ LI (lux) } & \multirow[b]{2}{*}{ Cv. } & \multirow[b]{2}{*}{ LI } & \multirow[b]{2}{*}{ Cv.-LI } & \multicolumn{3}{|c|}{ LI (lux) } & \multirow[b]{2}{*}{ Cv. } & \multirow[b]{2}{*}{ LI } & \multirow[b]{2}{*}{ Cv.-LI } \\
\hline & 140 & 1,020 & 4,860 & & & & 140 & 1,020 & 4,860 & & & \\
\hline \multicolumn{13}{|l|}{ Stem } \\
\hline $\mathrm{YC}$ & $138.8 \pm 4.1$ & $158.4 \pm 5.2$ & $173.4 \pm 3.8$ & $\mathrm{YC} \mathrm{a}$ & $140 \mathrm{c}$ & ns & $98.2 \pm 9.5$ & $130.5 \pm 13.7$ & $187.0 \pm 24.3$ & $\mathrm{YC} \mathrm{a}$ & $140 \mathrm{~b}$ & ns \\
\hline $\mathrm{EC}$ & $119.8 \pm 3.7$ & $130.4 \pm 6.2$ & $140.4 \pm 3.1$ & $\mathrm{EC} \mathrm{b}$ & $1,020 \mathrm{~b}$ & $\ldots$ & $82.2 \pm 9.4$ & $66.2 \pm 11.6$ & $104.5 \pm 18.8$ & $\mathrm{EC} \mathrm{b}$ & $1,020 \mathrm{~b}$ & $\ldots$ \\
\hline$P$ values ${ }^{\mathrm{z}}$ & $\begin{array}{ll}\cdots & \\
& \ldots\end{array}$ & $\cdots$ & $\ldots$ & $\begin{array}{c}\ldots \\
<0.0001\end{array}$ & $\begin{array}{l}4,860 \mathrm{a} \\
<0.0001\end{array}$ & $\begin{array}{c}\ldots \\
0.3106\end{array}$ & $\begin{array}{l}\ldots \\
\ldots\end{array}$ & $\begin{array}{l}\ldots \\
\ldots\end{array}$ & $\begin{array}{l}\ldots \\
\ldots\end{array}$ & $\begin{array}{c}\ldots \\
<0.0001\end{array}$ & $\begin{array}{r}4,860 \mathrm{a} \\
0.0007\end{array}$ & $\begin{array}{c}\ldots \\
0.0763\end{array}$ \\
\hline \multicolumn{13}{|l|}{ Leaves } \\
\hline YC & $427.5 \pm 96.7$ & $91.6 \pm 37.3$ & $80.4 \pm 24.9$ & $\mathrm{YC} \mathrm{b}$ & $140 \mathrm{a}$ & ns & $\ldots$ & $\cdots$ & $\ldots$ & $\cdots$ & $\ldots$ & $\ldots$ \\
\hline $\mathrm{EC}$ & $522.5 \pm 45.7$ & $325.4 \pm 81.4$ & $201.2 \pm 54.1$ & $\mathrm{EC} \mathrm{a}$ & $1,020 \mathrm{~b}$ & $\cdots$ & $\ldots$ & $\cdots$ & $\ldots$ & $\ldots$ & $\ldots$ & $\ldots$ \\
\hline$P$ values ${ }^{\mathrm{z}}$ & $\begin{array}{l}\cdots \\
\cdots\end{array}$ & $\begin{array}{l}\cdots \\
\ldots\end{array}$ & $\begin{array}{l}\cdots \\
\cdots\end{array}$ & 0.0023 & $\begin{array}{l}4,860 \mathrm{~b} \\
<0.0001\end{array}$ & 0.4146 & $\begin{array}{l}\ldots \\
\ldots\end{array}$ & $\begin{array}{l}\cdots \\
\cdots\end{array}$ & $\begin{array}{l}\ldots \\
\ldots\end{array}$ & $\begin{array}{l}\ldots \\
\ldots\end{array}$ & $\begin{array}{l}\ldots \\
\ldots\end{array}$ & $\begin{array}{l}\ldots \\
\ldots\end{array}$ \\
\hline
\end{tabular}

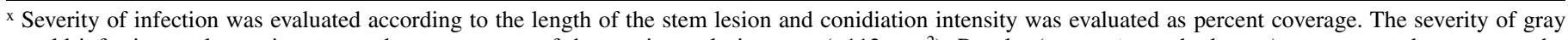
mold infection on leaves is expressed as percentage of the maximum lesion area $\left(=113 \mathrm{~mm}^{2}\right)$. Results (means \pm standard error) are presented as areas under disease progress curves (AUDPC; centimeters by days) through 7 days after infection; each mean is an average of eight replicates. Plants were incubated at $20 \pm$

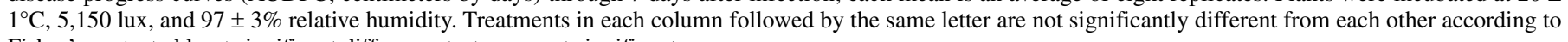
Fisher's protected least significant difference test; ns = not significant.

y Cultivars Yellow Catalina (YC) and Echo Champagne (EC) for excised stem pieces (Stem) and excised leaves (Leaves).

${ }^{z} P$ values for significance of major treatment factors and their combinations. 
this experiment (data not shown). Correlations of microclimate data and disease incidence were similar to those observed in experiment 1 (data not shown).

Microclimate in greenhouse experiments. There was no significant difference in temperature during the night among plots for the different treatments of the 2004-05 greenhouse experiment. However, some differences in RH were observed among treatments. The highest RH was recorded for the surface dripirrigation plots, followed by the polyethylene soil cover plots, with the lowest $\mathrm{RH}$ recorded in the combined treatment of soil cover with buried drip irrigation. The amount of time during which dew was detected in different plots differed, with the longest duration of dew in the most humid plots and the shortest duration on plants in the least humid plots (Fig. 8). Similarly, the average amounts of time during which the RH was $\geq 90 \%$ in the buried drip irrigation and control plots of the 2006-07 experiment were 14.8 and $22.7 \mathrm{~h}$ /day, respectively, during January 2007 (difference was significant, $P \leq 0.05$ ).

From 89 through 140 days after planting, gray mold incidence in the 2004-05 experiment was positively correlated with the duration of temperatures of 10 to $25^{\circ} \mathrm{C}(P=0.965$ to 0.998$)$ and RH of 90 to $100 \%$ ( $P=0.901$ to 0.993$)$, and negatively correlated with RH of 60 to $70 \%(P=-0.965$ to -0.997$)$ for 1 to 3 weeks before disease evaluation. From 140 through 190 days after planting, the number of plants with gray mold was positively correlated with temperatures of 25 to $40^{\circ} \mathrm{C}(P=0.904$ to 0.993$)$.

During the day, temperatures were higher in plots with soil cover than in the bare-soil plots and, during the night, temperatures in these covered plots dropped more slowly than temperatures in the bare-soil plots. Differences in $\mathrm{RH}$ were observed among treatments. Higher RH was recorded for the bare-soil plots. More dew was detected in bare-soil plots compared with the polyethylene soil-cover plots (Fig. 8).

The phosphorus, magnesium, and calcium contents of the tissues of lisianthus plants sampled from the polyethylene mulch treatment were significantly higher than those of plants grown on bare soil (Table 8). Calcium fertilization significantly increased concentrations of $\mathrm{Ca}$ and $\mathrm{K}$ in plant tissues. Higher levels of these elements were found in older leaves than in younger leaves (Table 8).

Effect of calcium nitrate. When $\mathrm{Ca}\left(\mathrm{Ca}\left(\mathrm{NO}_{3}\right)_{2}, 0.1 \mathrm{~g} / \mathrm{ml}\right)$ was applied to lisianthus plants $24 \mathrm{~h}$ before inoculation, the severity of leaf infection was significantly reduced $(P=0.0001)$ from $15 \%$ in the control plots to $5 \%$ at 7 days after inoculation, whereas applications applied $1 \mathrm{~h}$ after infection resulted in no disease control. Stem lesions reached up to $34.2 \mathrm{~mm}$ in length and exhibited up to $26.7 \%$ conidiation after 7 days. Calcium spray treatments applied before or after inoculation reduced infection severity; whereas conidiation observed for the two treatments reached 18.9 and $19.2 \%$, significantly different from the untreated control $(P \leq$ $0.05)$. Stem cuts and stem wounds on whole plants were treated by drenching with $\mathrm{Ca}\left(\mathrm{NO}_{3}\right)_{2}(0.1 \mathrm{~g} / \mathrm{ml})$. Severity of stem infection in the stem pieces and whole-plant stem cuts reached 49.6 and $29.9 \mathrm{~mm}$ (lesion length), respectively, after 7 days of incubation and was significantly $(P \leq 0.05)$ reduced by the $\mathrm{Ca}$ drench treatment to 34.2 and $21.3 \mathrm{~mm}$ for the stem pieces and whole plants, respectively. Intensity of conidiation in the stem pieces and whole-plant stem wounds reached 39.6 and $26.8 \%$, respectively, after 7 days of incubation and was significantly $(P \leq 0.05)$ reduced to 22.1 and $15.3 \%$ by the Ca drench treatment.

In the third greenhouse experiment, the incidence of gray mold on lisianthus plants 115 days after planting was 12.6 whole plants $/ \mathrm{m}^{2}$ and 39.7 plant stubs $/ \mathrm{m}^{2}$. Infection in the Ca spraytreated plots reached 8.2 whole plants $/ \mathrm{m}^{2}$ (significantly different from the control, $P \leq 0.05$ ) and 40.3 plant $\mathrm{stubs} / \mathrm{m}^{2}$.

\section{DISCUSSION}

Stem infection is the most devastating symptom of gray mold on lisianthus grown in greenhouses for cut flowers (49). Most stem infections result in plant death (50). Therefore, prevention of stem infection is an important goal of gray mold management strategies. In lisianthus, the stem base is normally infected by $B$. cinerea, in contrast to other crops in which infections by $B$. cinerea may occur all along the stem and not necessarily at the stem base (17). The localization of $B$. cinerea infections at the stem base of lisianthus may be due to a specific niche situation involving the most susceptible host tissue. It is also possible that the microclimatic conditions at the stem bases may be particularly favorable for infection of the host by $B$. cinerea. It should also be noted that these two possibilities are not mutually exclusive.

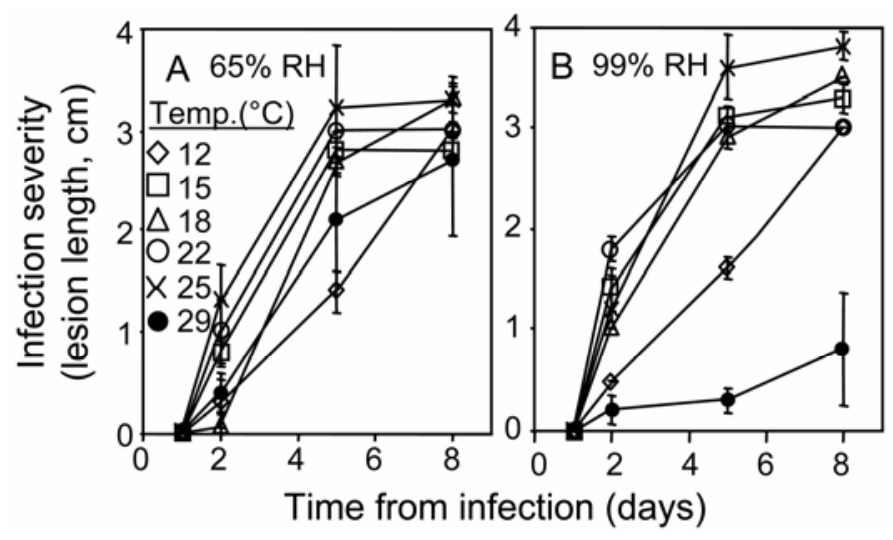

Fig. 4. Effects of temperature and relative humidity on severity of Botrytis cinerea infection on lisianthus stem pieces that were excised by a horizontal cut. Severity of infection is expressed as length of the lesion along the stem. Bars represent the standard error of each mean. Each mean is an average of six replicates.

TABLE 3. Effects of temperature (Tm) and relative humidity $(\mathrm{RH})$ on the rate of development of infection along attached lisianthus leaves

\begin{tabular}{|c|c|c|c|c|c|c|c|c|c|c|}
\hline \multirow[b]{2}{*}{$\operatorname{Tm}\left({ }^{\circ} \mathrm{C}\right)$} & \multirow[b]{2}{*}{ Node } & \multicolumn{4}{|c|}{$\mathrm{RH}(\%)$} & \multirow[b]{2}{*}{$\operatorname{Tm}\left({ }^{\circ} \mathrm{C}\right)$} & \multirow[b]{2}{*}{$\mathrm{RH}(\%)$} & \multirow[b]{2}{*}{ Node } & \multirow[b]{2}{*}{ Inter. } & \multirow[b]{2}{*}{$P$} \\
\hline & & $91-94$ & $95-96$ & $97-99$ & $>99$ & & & & & \\
\hline \multirow[t]{2}{*}{18} & 0 & $2.20 \pm 0.32$ & $3.27 \pm 0.46$ & $2.94 \pm 0.49$ & $3.10 \pm 0.95$ & $18 \mathrm{a}$ & $91-94$ b & $0 \mathrm{a}$ & RH-Node & 0.3842 \\
\hline & 5 & $1.17 \pm 0.39$ & $2.60 \pm 0.59$ & $1.29 \pm 0.95$ & $3.20 \pm 0.69$ & $\ldots$ & $\ldots$ & $\ldots$ & $\ldots$ & $\ldots$ \\
\hline \multirow[t]{2}{*}{20} & 0 & $3.67 \pm 0.21$ & $2.20 \pm 0.58$ & $2.67 \pm 0.60$ & $3.92 \pm 1.10$ & $20 \mathrm{a}$ & $95-96 \mathrm{ab}$ & $5 \mathrm{~b}$ & Tm-Node & 0.4038 \\
\hline & 5 & $2.98 \pm 0.25$ & $2.56 \pm 0.85$ & $2.75 \pm 0.85$ & $2.58 \pm 0.56$ & $\ldots$ & $\ldots$ & $\ldots$ & $\ldots$ & $\ldots$ \\
\hline \multirow[t]{2}{*}{26} & 0 & $1.19 \pm 0.35$ & $0.96 \pm 0.08$ & $0.27 \pm 0.11$ & $2.94 \pm 0.52$ & $26 \mathrm{~b}$ & $97-99 \mathrm{ab}$ & $\ldots$ & Tm-RH-Node & 0.7173 \\
\hline & 5 & $0.73 \pm 0.52$ & $0.54 \pm 0.64$ & $0.31 \pm 0.11$ & $1.46 \pm 0.31$ & $\begin{array}{l}\ldots \\
\ldots\end{array}$ & $\begin{array}{c}\ldots \\
>99 a\end{array}$ & $\begin{array}{l}\ldots \\
\ldots\end{array}$ & $\begin{array}{l}\cdots \\
\text { Tm-RH }\end{array}$ & $\begin{array}{c}\ldots \\
0.0279\end{array}$ \\
\hline$P$ values ${ }^{\mathrm{z}}$ & $\ldots$ & $\ldots$ & $\ldots$ & $\ldots$ & $\ldots$ & $<0.0001$ & 0.0080 & 0.0014 & $\ldots$ & $\ldots$ \\
\hline
\end{tabular}

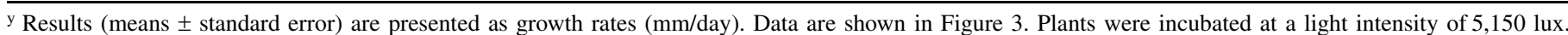
Treatments in each column followed by the same letter are not significantly different from each other according to Fisher's protected least significant difference test.

${ }^{\mathrm{z}} P$ values for significance of major treatment factors and their combinations; Node $=$ leaf positions and Inter. $=$ interactions. 
Nevertheless, in laboratory experiments in this study, the lower stem node was not more susceptible to $B$. cinerea than higher stem nodes. Under the controlled conditions of this study, the middle stem sections were more susceptible than the lower stem parts. Thus, localization of infection of $B$. cinerea at the stem base could not be attributed to any innate higher susceptibility of these lower nodes.

In greenhouse experiments, $B$. cinerea infection was observed to progress along the lower leaves of lisianthus toward the stem base (Y. Elad, unpublished data). In a similar study in unheated

TABLE 4. Effects of temperature and relative humidity $(\mathrm{RH})$ on the severity of Botrytis cinerea infection and conidiation on excised lisianthus stem pieces ${ }^{\mathrm{z}}$

\begin{tabular}{|c|c|c|c|c|c|c|}
\hline \multirow[b]{2}{*}{ Temperature $\left({ }^{\circ} \mathrm{C}\right)$} & \multicolumn{6}{|c|}{$\mathrm{RH}(\%)$} \\
\hline & 65 & 75 & 85 & 94 & 97 & 99 \\
\hline \multicolumn{7}{|l|}{ Infection severity } \\
\hline 12 & 9.4 c C & $9.2 \mathrm{~d} \mathrm{C}$ & $11.5 \mathrm{~d} \mathrm{~A}$ & $9.9 \mathrm{~b} \mathrm{BC}$ & $11.1 \mathrm{~b} \mathrm{AB}$ & 10.5 c ABC \\
\hline 15 & $13.3 \mathrm{ab} \mathrm{D}$ & 14.8 c C & $14.6 \mathrm{c} \mathrm{CD}$ & 16.7 a A & $15.3 \mathrm{a} \mathrm{BC}$ & $16.4 \mathrm{~b} \mathrm{AB}$ \\
\hline 18 & $14.6 \mathrm{ab} \mathrm{C}$ & $17.8 \mathrm{~b} \mathrm{~A}$ & $17.3 \mathrm{~b} \mathrm{AB}$ & 16.6 a $\mathrm{AB}$ & 18.4 a A & 17.7 b A \\
\hline 22 & 16.0 a C & $20.8 \mathrm{ab} \mathrm{A}$ & $18.1 \mathrm{~b} \mathrm{~B}$ & 18.2 a B & 17.9 a BC & $18.0 \mathrm{ab} \mathrm{BC}$ \\
\hline 25 & 17.8 a A & $21.2 \mathrm{a} \mathrm{A}$ & $21.2 \mathrm{a} \mathrm{A}$ & $18.2 \mathrm{a} \mathrm{A}$ & $17.1 \mathrm{a} \mathrm{A}$ & 19.8 a A \\
\hline 29 & $11.3 \mathrm{bc} \mathrm{A}$ & $11.2 \mathrm{~d} \mathrm{~A}$ & 4.7 e B & $1.8 \mathrm{~b} \mathrm{~B}$ & $2.7 \mathrm{c} \mathrm{B}$ & $2.6 \mathrm{~d} \mathrm{~B}$ \\
\hline \multicolumn{7}{|l|}{ Conidiation } \\
\hline 12 & $0.0 \mathrm{~b} \mathrm{~B}$ & $3.0 \mathrm{c} \mathrm{B}$ & $24.0 \mathrm{bc} \mathrm{A}$ & $30.0 \mathrm{c} \mathrm{A}$ & $23.7 \mathrm{~b} \mathrm{~A}$ & $18.0 \mathrm{~b} \mathrm{~A}$ \\
\hline 15 & 15.0 a B & $24.3 \mathrm{bc} \mathrm{B}$ & 50.4 b B & $123.0 \mathrm{~b} \mathrm{~A}$ & 99.6 a A & $120.0 \mathrm{a} \mathrm{A}$ \\
\hline 18 & 16.5 a B & $35.1 \mathrm{a} \mathrm{B}$ & 130.6 a A & $172.0 \mathrm{a} \mathrm{A}$ & $113.5 \mathrm{a} \mathrm{A}$ & $152.5 \mathrm{a} \mathrm{A}$ \\
\hline 22 & 12.9 a B & 60.3 a B & 146.5 a A & $172.0 \mathrm{ab} A$ & 157.0 a A & $0.9 \mathrm{~b} \mathrm{~B}$ \\
\hline 25 & 15.0 a B & $45.9 \mathrm{ab} \mathrm{A}$ & $46.0 \mathrm{~b} \mathrm{~A}$ & 36.9 с AB & 29.7 b AB & $9.0 \mathrm{~b} \mathrm{~B}$ \\
\hline 29 & $0.0 \mathrm{~b}-$ & $0.0 \mathrm{c}-$ & $0.0 \mathrm{c}-$ & $0.0 \mathrm{c}-$ & $23.7 \mathrm{~b}-$ & $0.9 \mathrm{~b}-$ \\
\hline
\end{tabular}

${ }^{\mathrm{z}}$ Results (means \pm standard error) are presented as areas under disease progress curves (AUDPC; centimeters by days for infection and percent by days) through 8 days after infection (results of two RH levels are presented in Figure 4). Plants were incubated at a light intensity of 5,150 lux. Treatments in each RH column followed by the same lowercase letter and in each temperature row followed by the same uppercase letter are not significantly different from each other according to Fisher's protected least significant difference test. Because the interaction of temperature-RH was found to significantly affect infection severity and conidiation $(P<0.0001)$, the general effects of each parameter were not tested.
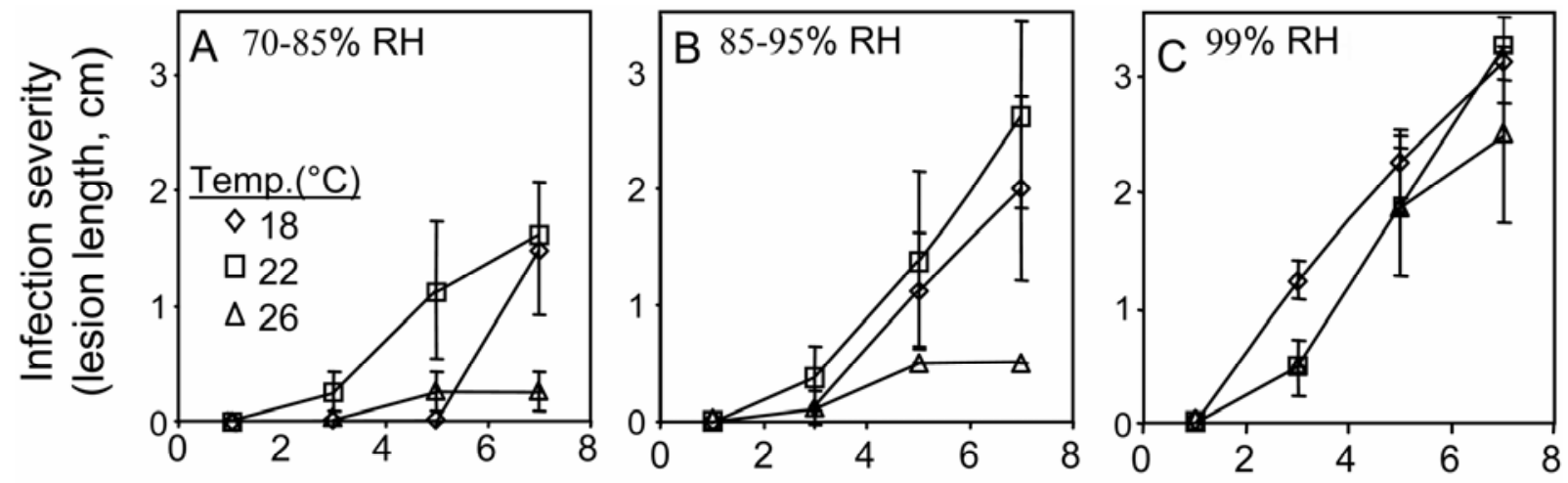

Time from inoculation (days)

Fig. 5. Effects of temperature and relative humidity on severity of Botrytis cinerea infection on stem wounds of lisianthus plants. Severity is expressed as length of the gray mold lesion along the stem. Bars represent the standard error of each mean. Each mean is an average of eight replicates.

TABLE 5. Effects of temperature (Tm) and relative humidity $(\mathrm{RH})$ on the severity of infection and conidiation on lisianthus stem wounds on whole plants ${ }^{\mathrm{x}}$

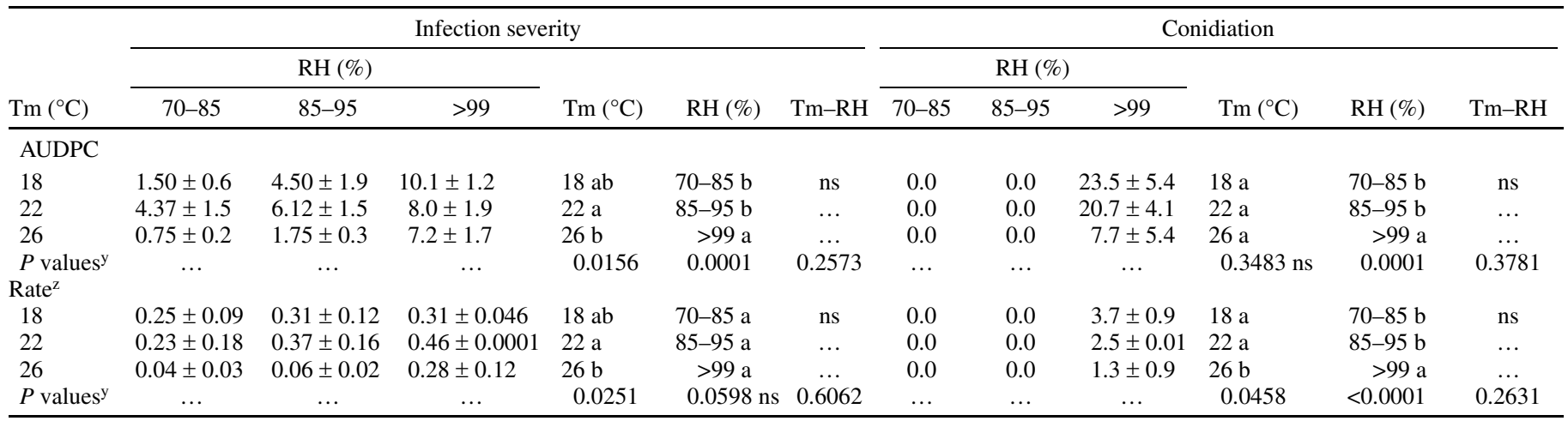

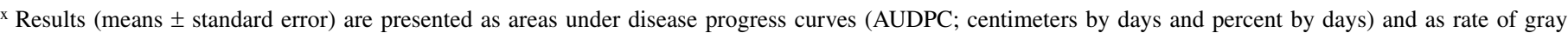
mold development through 7 days after infection and rate $(\mathrm{cm} /$ day) of disease development. Plants were incubated at a light intensity of 5,150 lux. Treatments in each column of either AUDPC or rate value followed by the same letter are not significantly different from each other according to Fisher's protected least significant difference test; $\mathrm{ns}=$ not significant.

y $P$ values for significance of major treatment factors and their combinations.

${ }^{\mathrm{z}}$ Rate of development. 
greenhouses, most tomato stem lesions were found to have originated from progression of $B$. cinerea along infected leaves (38). Under the controlled conditions of this study, infection progressed more quickly on the lower leaves of lisianthus than the upper leaves. The rate at which $B$. cinerea was reported to progress along infected tomato leaves was 3 to $5 \mathrm{~mm}$ /day (38); whereas, on lisianthus leaves in this study, infection progressed 0.7 to 3.9 $\mathrm{mm} /$ day, a slightly slower rate than that observed on tomato leaves. Nevertheless, assuming that a typical lisianthus leaf is $10 \mathrm{~cm}$ long and that infection typically occurs in the middle of the leaf, it would take at least 12.8 days for $B$. cinerea infection to reach the stem. Two environmental factors appeared to govern the rate at which infection progressed along the lisianthus leaf in this study. At 18 to $26^{\circ} \mathrm{C}$, the higher temperature was associated with the lowest levels of disease. This contrasts with findings on tomato leaves, where higher temperatures, within the range of 5 to $30^{\circ} \mathrm{C}$, were associated with more rapid pathogen progression (38). This finding also contrasts with an earlier report on geranium (29) and the fact that conidia and mycelia of $B$. cinerea were found to survive better at 0 to $20^{\circ} \mathrm{C}$ (45). Lisianthus leaf infection developed more quickly at higher RH levels ( $\geq 95 \%)$, similar to field bean leaves on which the rate of increase in $B$. fabae infection was linear and proportional to RH between 70 and 100\% (23). In contrast, gray mold on tomato leaves developed more quickly at the lower RH levels of 70 to $85 \%$ (38).

During gray mold development, the lisianthus plant canopy is usually dense and high RH levels are found at the lower and middle heights of the canopy. Thus, high RH alone might not be correlated with the prevalence of stem base infections in this plant species. It was hypothesized that lower light intensity within the canopy might be correlated with higher levels of stem gray mold. However, this hypothesis was not supported by the results of this study, in which gray mold severity and conidiation intensity were greater under higher light intensity. This contrasts with studies on gray mold of strawberry (36), black spruce (Picea mariana) (54), and fava bean (Vicia faba) (23). In the strawberry study, illumination of plants $\left(17.5 \mathrm{~W} / \mathrm{m}^{2}\right.$ for $2 \mathrm{~h}$ at $\left.2^{\circ} \mathrm{C}\right)$ delayed the appearance of gray mold symptoms on fruit of $\mathrm{cv}$. Ofra that had been inoculated with $B$. cinerea (39). Similarly, in studies of black spruce seedlings in greenhouses, conidiation incidence (a measure of disease severity) decreased as light intensity increased, and reached zero when the mean light intensity at noon on sunny days was near $10 \mu \mathrm{mol} / \mathrm{m}^{2} / \mathrm{s}$. It was concluded that a light intensity (wavelength of 400 to $700 \mathrm{~nm}$ ) of $\leq 10 \mu \mathrm{mol} / \mathrm{m}^{2} / \mathrm{s}$ predisposed the needles to infection by $B$. cinerea (54). In another study, light intensity did not affect growth of $B$. fabae on the leaves of fava bean (23).

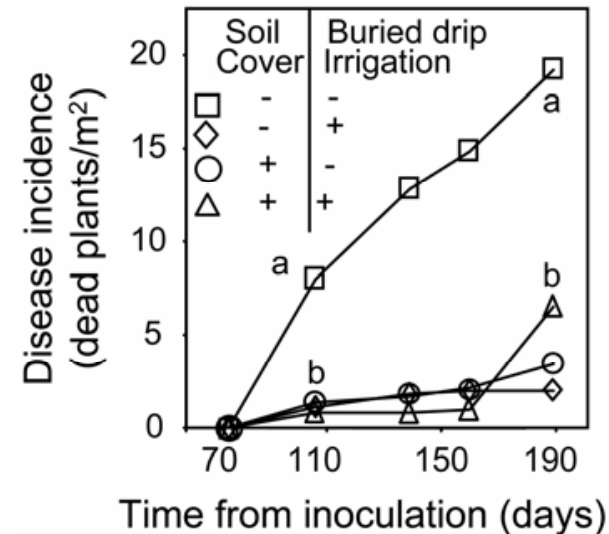

Fig. 6. Effects of deep drip irrigation $(=+)$ and polyethylene soil cover $(=+)$ $(-=$ no treatment $)$ on the incidence of gray mold on lisianthus stems in a greenhouse experiment in walk-in tunnels in 2004-05 (expressed as number of dead plants). Different letters represent significant differences according to Fisher's protected least significant difference test $(P \leq 0.05)$. Each mean is an average of four replicates.
The higher severity of $B$. cinerea infection on lower as opposed to upper lisianthus leaves might be explained by the maturity of the leaves $(11,13)$. This was demonstrated on geranium (Pelargonium hortorum) leaves infected by $B$. cinerea (40). In that study, the incidence of infection increased as plants aged from 4 to 10 weeks (40). Similarly, in a study of young and old leaves of fava bean plants grown outdoors and inoculated with $B$. fabae conidia, the oldest leaves developed more lesions than the youngest leaves and, on intact plants kept at high $\mathrm{RH}$, established lesions on young leaves increased in size at only half the rate of those on older (but still green) leaves (26). B. cinerea infection spread more quickly in the lamina of old tobacco leaves than in that of young leaves (24). Similarly, senescent and mature plant material acted as a focal point for infection and conidiation in lentil (Lens culinaris) (7).

In this study, specific conditions at the stem base of lisianthus were found to be related to the fact that the lower leaves were in close contact with the wet soil. When a barrier, in the form of a polyethylene sheet, was placed between the lower leaves and the wet soil, disease severity on those leaves was significantly reduced under the controlled laboratory conditions used in this study and in the two commercial experiments.

A lisianthus plant has one stem, at the top of which flowers develop (49). Once harvest begins, the stems are removed and a 10 -cm-long stem base is left along with the basal rosette leaves. The short, cut stems are readily exposed to infection by $B$. cinerea. This infection then spreads to the leaves and infection develops along the leaves toward the stem base, as described above for whole plants (Y. Elad, personal observation). Furthermore, the wound formed during flower harvest also serves as an infection site, as has been described for sweet basil (37). Plants that are infected at this stage fail to produce new branches that would be harvested at the second flower harvest. It has been reported that the harvesting method and the nature of the wound are important for gray mold development (8). In tomato, pruning leaves by hand results in larger, more ragged wounds than removing leaves with a knife or scissors (8). The smaller wounds are much less susceptible to $B$. cinerea and heal more quickly than the bigger wounds on tomato (46). Surprisingly, in the current study, horizontal stem cuts, which produce wounds smaller than those caused by diagonal wounding, resulted in infection severity and higher levels of conidiation of $B$. cinerea similar to those observed in the diagonal wounds. This may reflect similarities in the food base and moisture conditions that the wounds provide the pathogen for infection and establishment in the host tissue.

We are not aware of a lisianthus breeding program focused on developing resistance to $B$. cinerea. Nevertheless, it may be valuable to test the potential susceptibility of different lisianthus

TABLE 6. Effects of deep drip irrigation (dDrip) and polyethylene soil cover on gray mold of lisianthus stems and flower yield in a greenhouse experiment in walk-in tunnels in 2004-05

\begin{tabular}{lccccc}
\hline & & Dead plants & & \multicolumn{2}{c}{ Yield (flowers $/ \mathrm{m}^{2}$ ) } \\
\cline { 3 - 3 } \cline { 5 - 6 } Soil mulch & Drip & AUDPC & & 1st flowering & 2nd flowering \\
\hline Bare soil & Surface & $2,432.0 \mathrm{a}$ & & $69.1 \pm 2.0 \mathrm{a}$ & $107.2 \pm 16.1 \mathrm{~b}$ \\
Soil mulch & Surface & $374.8 \mathrm{~b}$ & & $65.3 \pm 3.5 \mathrm{a}$ & $85.7 \pm 5.2 \mathrm{c}$ \\
Bare soil & Buried & $321.5 \mathrm{~b}$ & & $65.9 \pm 2.9 \mathrm{a}$ & $99.3 \pm 12.1 \mathrm{bc}$ \\
Soil mulch & Buried & $331.0 \mathrm{~b}$ & & $70.2 \pm 1.5 \mathrm{a}$ & $133.2 \pm 7.2 \mathrm{a}$ \\
\hline
\end{tabular}

y Results are presented as means \pm standard error. Dead plant results are presented as areas under disease progress curves (AUDPC) for 70 through 190 days after planting (number-days). Treatments in each column followed by the same letter are not significantly different from each other according to Fisher's protected least significant difference test. The soil mulch-drip irrigation interaction was significant for the disease and yield parameters $(P=0.0042-0.0093)$; therefore, the effects of these main factors are not presented.

z Incidence of dead plants. 
cultivars to the pathogen. Wegulo and Vilchez (49) used various techniques to evaluate 12 lisianthus cultivars for resistance to $B$. cinerea and found that lisianthus cultivars with moderate resistance to $B$. cinerea are commercially available. In the present study, lisianthus cv. Yellow Catalina was moderately more susceptible than cv. Echo Champagne in the stem cut assay whereas the leaf bioassay showed the opposite result, with Echo Champagne more susceptible to gray mold than Yellow Catalina, especially under higher light intensities. This discrepancy might be better understood in light of a previous study (49), which reported that $B$. cinerea infection severity varied based on the bioassay used and the inoculation method.

The use of stem pieces for the study of lisianthus wound infections enabled testing of a range of temperatures and RH. The temperature range associated with greater severity of gray mold was wider at the higher RH levels tested (94 to 99\%) than at the lower RH levels (65 to 85\%). The RH range at which infection occurred was wide, 65 to $99 \%$. Similarly, a low level of gray mold infection was observed at $56 \% \mathrm{RH}$ in stem wounds of greenhouse tomato (10). Stem infection at low RH is an exception because $B$. cinerea usually does not infect plants at low RH $(8,12,16$ $19,35,37,38)$. Infection at low RH is probably enabled by the fact that the wound surface remains wet for a period after the wound is formed $(8,35,37,38)$. In a study of stem infection of sweet basil by $B$. cinerea, wounds remained receptive to infection by $B$. cinerea conidia $24 \mathrm{~h}$ after wounding (37). The optimal $\mathrm{RH}$ range for infection of stem wounds in sweet basil and tomato was 75 to $85 \%(35,37)$. Therefore, it is surprising that infection of lisianthus stem wounds occurred more readily at $\mathrm{RH}$ levels as high as $99 \%$ within a very wide temperature range, 12 to $29^{\circ} \mathrm{C}$.

Infection of lisianthus stem wounds in potted plants by $B$. cinerea enabled us to estimate more clearly the range of conditions under which lisianthus is infected by $B$. cinerea. The higher the RH (70 to 85 versus $>99 \%$ ), the broader the temperature range $\left(18,22\right.$, and $\left.26^{\circ} \mathrm{C}\right)$ that allowed severe, more rapid gray mold development. Similar to results observed in the experiment with lisianthus stem pieces and unlike results of studies of tomato and sweet basil stem infections $(35,37)$, high RH levels were associated with higher levels of gray mold on lisianthus stems in this study. Conidiation of B. cinerea on lisianthus stems was observed at all temperatures $\left(18,22\right.$, and $\left.26^{\circ} \mathrm{C}\right)$ but only at $\mathrm{RH}$ of $99 \%$; at $26^{\circ} \mathrm{C}$, there was less conidiation than at the other temperatures. Similarly, conidiation of $B$. cinerea at $28^{\circ} \mathrm{C}$ was observed on black spruce (53). The temperature limit for $B$. cinerea conidiation on lentil (L. culinaris) was $30^{\circ} \mathrm{C}(7)$ whereas, on tomato stem wounds, conidiation did not occur within 20 days of incubation at 5 or $26^{\circ} \mathrm{C}$ (35). The fact that $B$. cinerea did not conidiate at $\mathrm{RH}$ $\leq 95 \%$ in this study on lisianthus contradicts earlier findings. For instance, on tomato stem wounds, conidiation occurred at $45 \%$;

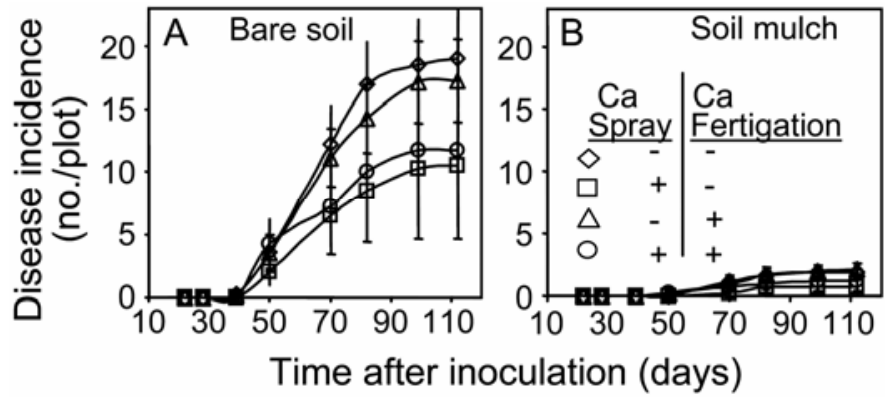

Fig. 7. Effects of polyethylene soil cover, Ca sprays $(=+)$, and fertigation (= $+)$ treatments $(-=$ no treatment $)$ on the incidence of gray mold on lisianthus stems in a greenhouse experiment in walk-in tunnels in 2005-06 (expressed as number of dead plants) in Israel. Bars represent the standard error of each mean. Each mean is an average of four replicates for the main treatment and six randomized replicates for the split-plot treatments.

TABLE 7. Effects of polyethylene soil cover and calcium spray treatments on gray mold of lisianthus stems and flower yield in a greenhouse experiment in walkin tunnels in $2005-06^{\mathrm{w}}$

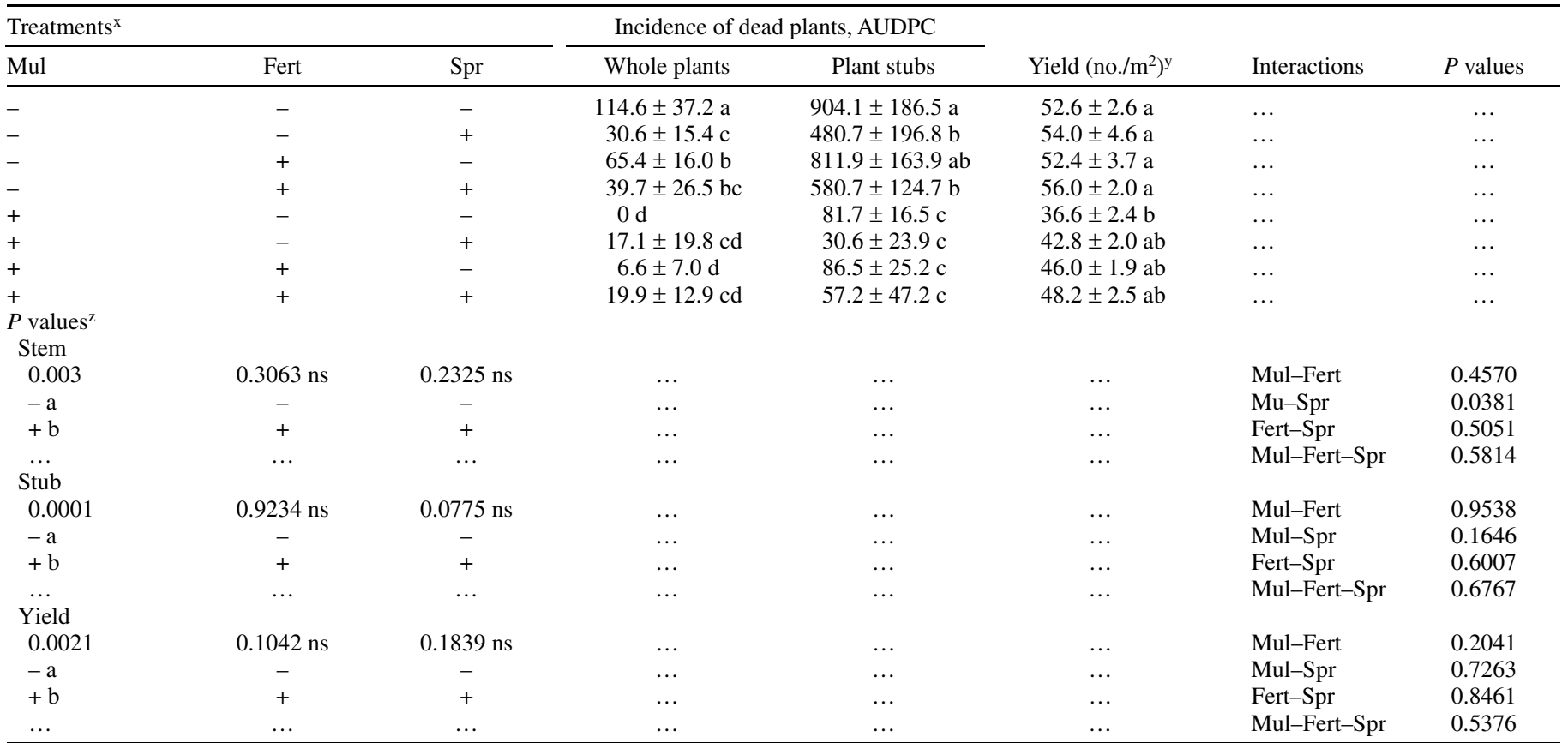

${ }^{\mathrm{w}}$ Dead plant results are presented as areas under disease progress curves (AUDPC) for 20 through 110 days after inoculation (number-days). Treatments in each column followed by the same letter are not significantly different from each other according to Fisher's protected least significant difference test; ns = not significant.

${ }^{\mathrm{x}}$ Treatments consisted of combinations of either soil cover $(+)$ or bare soil $(-)$ with fertigation with calcium or no fertigation; Mul $=$ soil mulch, Fert $=$ Ca fertigation, and $\mathrm{Spr}=\mathrm{Ca}$ spray.

${ }^{y}$ Flower yield, first flowering.

${ }^{z} P$ values for significance of major treatment factors and their combinations; Stem $=$ whole plant stem infection and Stub $=$ plant stub infection. 
however, higher RH levels did increase the intensity of conidiation (35).

The ultimate goal of this study was to identify cultural strategies for suppressing infection of lisianthus stems by B. cinerea. Similar studies on gray mold have suggested the use of heating or aeration and ventilation of the greenhouse $(8,10,15,21,30,34)$ in order to reduce humidity levels and the amount of dew on susceptible plant tissues. However, heating has been abandoned by most lisianthus farmers in Israel because of its high cost (Y. Elad, personal information). Efforts to increase air movement in lisianthus crops were found to be practically ineffectual because of the dense crop canopy and the specific location of infection (i.e., the stem base). In the present study, we tested the effects of covering the greenhouse soil with polyethylene and burying the drip-irrigation system. We also tested the effects of applying different calcium fertilizer regimes to the canopy. Polyethylene soil cover and subsurface drip irrigation significantly decreased $\mathrm{RH}$ in the greenhouse and suppressed gray mold on the stem bases and cut stem ends.

Infection of the stem base by a pathogen is likely to be affected by soil moisture because of their proximity. The location of dripirrigation emitters affects soil moisture around the stem base and, thus, is also likely to affect infection of plants by $B$. cinerea. Café-Filho and Duniway (3) studied the effects of the location of drip-irrigation emitters and the position of inoculum in roots on Phytophthora root rot of pepper (Capsicum annuum). In field plots infested with Phytophthora capsici, they demonstrated that the location of emitters significantly affected soil moisture, incidence of diseased plants, and severity of root symptoms. The study found that the incidence of basal stem infection could be reduced in low-rainfall areas by positioning drip emitters away from plant stems, with a subsurface location (15 cm deep) giving the best results. Similarly, in the current lisianthus study, when drippers were placed $20 \mathrm{~cm}$ below the soil surface, the incidence of lisianthus stem infection was reduced by $87 \%$. The subsurface irrigation plots were characterized by lower RH and shorter dew periods than plots irrigated using an aboveground drip-irrigation system. The irrigation treatment did not significantly affect flower yields.

Mills et al. (33) found that early blight (Alternaria solani) and Septoria leaf spot (Septoria lycopersici) in fresh-market tomato crops were reduced in plots covered with black polyethylene compared with bare-soil plots. Soil coverage on tomato leaflets and soil particle dispersal were reduced in plots with polyethylene-covered soil versus bare soil, and leaf wetness duration was reduced in plots with polyethylene-covered soil compared with bare-soil plots. Mills et al. (33) concluded that an observed reduction in foliar disease in mulched plots was associated with
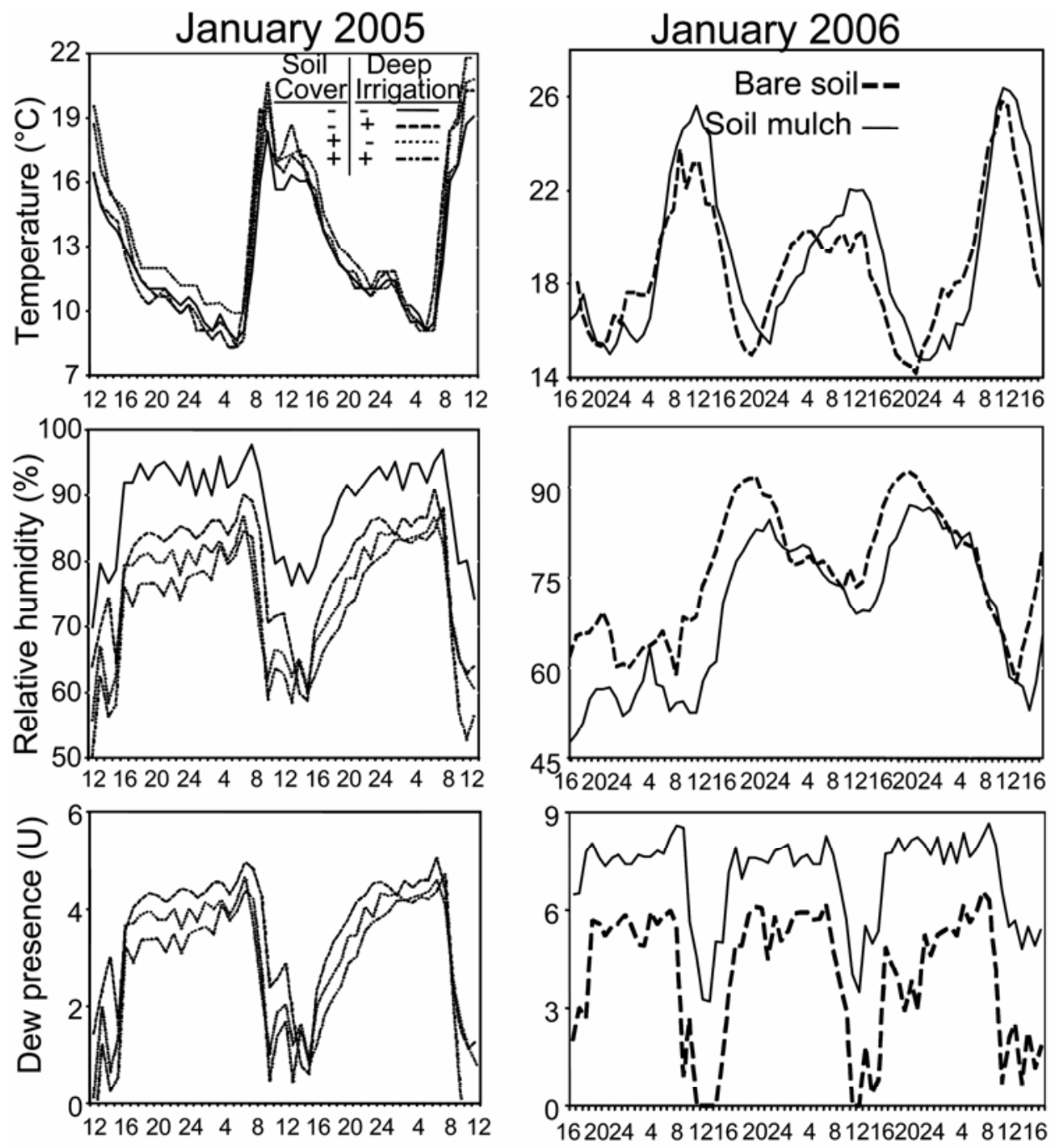

Time (hours)

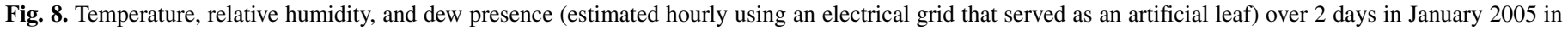

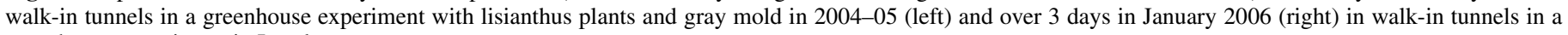
greenhouse experiment in Israel. 
reduced splash dispersal and, in one of two trials, reduced leaf wetness. Strawberry plants grown in beds covered with black polyethylene had lower incidences of $B$. cinerea-incited rot than those grown in beds covered with either clear polyethylene or paddy straw (35). Reducing air humidity by covering the soil with polyethylene has also been suggested as a means for restricting gray mold development in greenhouse crops $(12,15)$. In the two greenhouse lisianthus experiments in this study, polyethylene mulch reduced disease incidence by 85 to $100 \%$ and reduced RH and dew duration. The mechanisms by which lisianthus stem base infections are reduced through the use of polyethylene soil cover may be complex. The reductions in $\mathrm{RH}$ and the amount of dew in the canopy contribute to inhibition of the germination of $B$. cinerea conidia and host penetration by the fungus (28). Also, as shown in the laboratory experiments in this study, a physical barrier between the lower leaves and the wet soil affects conditions for development of infection along the leaves toward the stem base. Cohen et al. (5) supplied a detailed explanation for the effect of polyethylene mulch on a foliar disease of tomato. They found that covering the soil surface with polyethylene dramatically reduced the rate of $P$. infestans infection in the early winter compared with greenhouses with bare soil. Microclimate measurements showed that night-time soil and air temperatures were higher in mulched greenhouses. On days when infection occurred in the control plots, air temperature reached dew-point temperature in the control greenhouses but not in the mulched greenhouses. Night-time soil temperatures and air temperatures near the ground were higher under the mulch, and the difference between air temperature and dew point temperature in the greenhouse was higher above the mulch, indicating a lower incidence of condensation on the leaves (5). This temperature-dew effect explains part of the polyethylene effect on gray mold but not the effect of deep irrigation, which also affected the duration of wetness of the lower leaves and the air RH. Interestingly, plant tissues sampled in the mulched plots had relatively high levels of $\mathrm{N}, \mathrm{P}, \mathrm{K}, \mathrm{Ca}$, and $\mathrm{Mg}$ compared with tissues sampled in the nonmulched plots. This might contribute to disease control by changing the susceptibility of lisianthus tissues to $B$. cinerea infection. We are not aware of a description of such a phenomenon in the literature but this topic can be clarified with further research.

In this study, a positive correlation was found between wholeplant mortality and temperatures above 25 or $30^{\circ} \mathrm{C}$. This result is similar to a phenomenon reported for cucumber stem infection by $B$. cinerea, in which high temperature $\left(30^{\circ} \mathrm{C}\right)$ predisposed plants to infection and increased the incidence of disease when plants were incubated under conditions favorable for $B$. cinerea development (18). Moreover, once infection develops at the stem base of lisianthus plants, some xylem vessels may cease to function, limiting the movement of water from the roots so that, at high temperatures, there is not enough transpiration to the canopy and the plants collapse. Increased amounts of $\mathrm{Ca}$ in plant tissues have been associated with reduced susceptibility to $B$. cinerea infection and, in some cases, Ca fertilization has effectively reduced the severity of gray mold infections $(2,4,11,13,20,48,51)$. In the present study, we found that foliar calcium nitrate sprays reduced leaf infection of lisianthus under greenhouse conditions. Ca sprays also reduced whole-plant and cut-plant infections on bare soil, whereas $\mathrm{Ca}$ fertigation through drip irrigation reduced infection by $B$. cinerea only on whole plants on bare soil. Calcium treatments did not contribute as much as the polyethylene mulch to disease suppression, and the combination of calcium treatments with the polyethylene mulch resulted in a level of disease incidence similar to that observed for the mulch alone. Moreover, the combination of calcium spray applications and calcium fertigation was no better than calcium sprays alone. Calcium treatments resulted in higher levels of calcium and magnesium in the leaves, which might explain part of the effect of these treatments on disease $(1,2)$.

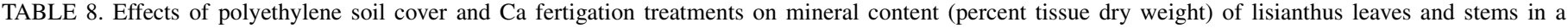
greenhouse experiment in walk-in tunnels in 2005-06

\begin{tabular}{|c|c|c|c|c|c|c|c|c|c|c|c|c|}
\hline \multirow[b]{5}{*}{ Element $^{\mathrm{x}}$} & \multirow[b]{5}{*}{ Sampled tissue } & \multicolumn{4}{|c|}{ Treatment $^{\mathrm{y}}$} & & & & & & & \\
\hline & & \multicolumn{4}{|c|}{ Soil mulch } & & & & & & & \\
\hline & & - & - & + & + & \multicolumn{7}{|c|}{$P$ values ${ }^{\mathrm{z}}$} \\
\hline & & \multicolumn{4}{|c|}{$\mathrm{Ca}$ fertigation } & \multicolumn{3}{|c|}{ Soil mulch $(\mathrm{S})$} & \multicolumn{3}{|c|}{$\mathrm{Ca}$ fertilization $(\mathrm{Ca})$} & \multirow{2}{*}{$\frac{\mathrm{S}-\mathrm{Ca}}{P}$} \\
\hline & & - & + & - & + & $P$ & - & + & $P$ & - & + & \\
\hline \multicolumn{13}{|l|}{ First sample } \\
\hline Nitrogen & Upper leaf & 2.19 & 2.39 & 2.64 & 2.56 & 0.008 & $\mathrm{~b}$ & $\mathrm{a}$ & 0.582 & ns & $\ldots$ & 0.184 \\
\hline Phosphorus & Upper leaf & 0.14 & 0.14 & 0.16 & 0.14 & 0.169 & ns & $\ldots$ & 0.513 & ns & $\ldots$ & 0.513 \\
\hline Potassium & Upper leaf & 1.42 & 1.63 & 1.66 & 1.81 & 0.001 & $\mathrm{~b}$ & $\mathrm{a}$ & 0.003 & $\mathrm{~b}$ & $\mathrm{a}$ & 0.630 \\
\hline Calcium & Upper leaf & 0.26 & 0.30 & 0.26 & 0.29 & 0.935 & ns & $\ldots$ & 0.297 & ns & $\ldots$ & 0.892 \\
\hline Magnesium & Upper leaf & 0.39 & 0.46 & 0.42 & 0.45 & 0.624 & ns & $\ldots$ & 0.011 & $\mathrm{~b}$ & $\mathrm{a}$ & 0.179 \\
\hline \multicolumn{13}{|l|}{ Second sample } \\
\hline \multirow[t]{3}{*}{ Nitrogen } & Lower leaf & 1.91 & 2.03 & 2.31 & 2.39 & 0.0002 & ns & $\ldots$ & 0.262 & ns & $\ldots$ & 0.763 \\
\hline & Upper leaf & 2.42 & 2.55 & 2.67 & 2.64 & 0.010 & ns & $\ldots$ & 0.495 & ns & $\ldots$ & 0.574 \\
\hline & Stem & 0.82 & 0.80 & 0.76 & 0.77 & 0.359 & ns & $\ldots$ & 0.985 & ns & $\ldots$ & 0.758 \\
\hline \multirow[t]{3}{*}{ Phosphorus } & Lower leaf & 0.09 & 0.09 & 0.11 & 0.11 & 0.0001 & $\mathrm{~b}$ & $\mathrm{a}$ & 0.564 & ns & $\ldots$ & 0.919 \\
\hline & Upper leaf & 0.12 & 0.12 & 0.14 & 0.15 & 0.0002 & $\mathrm{~b}$ & $\mathrm{a}$ & 0.815 & ns & $\ldots$ & 0.670 \\
\hline & Stem & 0.05 & 0.05 & 0.05 & 0.06 & 0.217 & ns & $\ldots$ & 0.959 & ns & $\ldots$ & 0.700 \\
\hline \multirow[t]{3}{*}{ Potassium } & Lower leaf & 4.26 & 4.43 & 4.22 & 5.41 & 0.1132 & ns & $\ldots$ & 0.024 & $\mathrm{~b}$ & $\mathrm{a}$ & 0.084 \\
\hline & Upper leaf & 4.03 & 4.79 & 4.49 & 5.18 & 0.185 & ns & $\ldots$ & 0.032 & $\mathrm{~b}$ & a & 0.918 \\
\hline & Stem & 2.50 & 3.06 & 2.60 & 3.04 & 0.812 & ns & $\ldots$ & 0.005 & $\mathrm{~b}$ & $\mathrm{a}$ & 0.718 \\
\hline \multirow[t]{3}{*}{ Calcium } & Lower leaf & 0.54 & 0.61 & 0.59 & 0.66 & 0.249 & $\mathrm{~ns}$ & $\ldots$ & 0.154 & ns & $\ldots$ & 0.844 \\
\hline & Upper leaf & 0.37 & 0.48 & 0.52 & 0.63 & 0.0014 & $\mathrm{~b}$ & $\mathrm{a}$ & 0.012 & $\mathrm{~b}$ & $\mathrm{a}$ & 0.935 \\
\hline & Stem & 0.09 & 0.13 & 0.10 & 0.09 & 0.089 & ns & $\ldots$ & 0.030 & $\mathrm{~b}$ & $\mathrm{a}$ & 0.180 \\
\hline \multirow[t]{3}{*}{ Magnesium } & Lower leaf & 0.74 & 0.79 & 0.82 & 0.91 & 0.014 & $\mathrm{~b}$ & $\mathrm{a}$ & 0.077 & ns & $\ldots$ & 0.633 \\
\hline & Upper leaf & 0.68 & 0.71 & 0.77 & 0.81 & 0.004 & $\mathrm{~b}$ & $\mathrm{a}$ & 0.216 & ns & $\ldots$ & 0.863 \\
\hline & Stem & 0.12 & 0.13 & 0.14 & 0.13 & 0.0437 & ns & $\ldots$ & 0.794 & ns & $\ldots$ & 0.265 \\
\hline
\end{tabular}

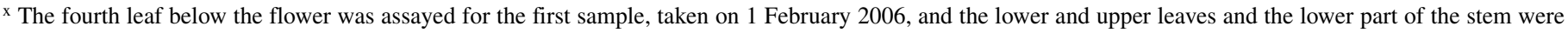
assayed in the second sample, taken on 6 June 2006.

y Soil was either covered with polyethylene (+) or left uncovered (-); supplementary calcium was either applied (+) or not applied (-).

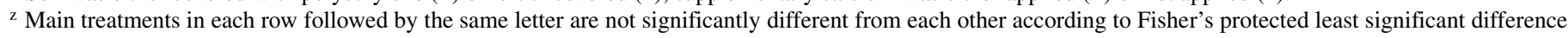
test. None of the interactions between the main treatments were found to be significant (right column); ns = not significant. 
In this study, various abiotic factors were found to affect different aspects of lisianthus stem infection by $B$. cinerea. Grower choice of cultivar may also affect disease development. Our results show that the conditions that prevail in unheated greenhouses in Israel promote the disease and present a major challenge for growers attempting to control gray mold by cultural means. Nevertheless, in greenhouses in which moisture at the soil surface is limited by polyethylene mulch or the use of subsurface drip irrigation, disease incidence will be reduced. Some additional measures of control may be needed, such as the use of botryticides during harvest when stem wounds are created. It may be possible to use the above results to develop an integrated gray mold control system that is more effective than current systems. It is hoped that other humidity-promoted diseases of lisianthus, such as downy mildew, will also be affected negatively by these cultural practices.

\section{ACKNOWLEDGMENTS}

Contribution no. 506/08 from the ARO, The Volcani Center, Bet Dagan, Israel. This research was supported by the Chief Scientist of the Israeli Ministry of Agriculture. We thank L. Ganot, D. Shmuel, and E. Matan from Research \& Development South, Besor Research Station and Y. Messika, M. Bruner, I. Nishri, and Y. Mor from the Israeli Extension Service for their help and cooperation.

\section{LITERATURE CITED}

1. Baas, R., Van Oers, S., Silber, A., Bernstein, N., Ioffe, M., Keinan, M., and Bar-Tal, A. 2003. Calcium distribution in cut roses as related to transpiration. J. Hortic. Sci. Biotechnol. 78:1-9.

2. Bar-Tal, A., Baas, R., Ganmore-Neumann, R., Dik, A., Marissen, N., Silber, A., Davidov, S., Hazan, A., Kirshner, B., and Elad, Y. 2001. Rose flower production and quality as affected by $\mathrm{Ca}$ concentration in the petal. Agronomie 21:393-402.

3. Café-Filho, A. C., and Duniway, J. M. 1996. Effect of location of drip irrigation emitters and position of Phytophthora capsici infections in roots on Phytophthora root rot of pepper. Phytopathology 86:1364-1369.

4. Chardonnet, C., and Doneche, B. 1995. Relation between calcium content and resistance to enzymatic digestion of the skin during grape ripening. Vitis 34:95-98.

5. Cohen, S., Ziv, G., Grava, A., Elad, Y., and Shtienberg, D. 2006. Influence of polyethylene mulch on night microclimate, dew point and Phytophthora infestans infection in non-heated tomato greenhouses in southern Israel. Acta Hortic. 718:277-282.

6. Cole, L., Dewey, F. M., and Hawes, C. R. 1996. Infection mechanisms of Botrytis species: pre-penetration and pre-infection processes of dry and wet conidia. Mycol. Res. 100:277-286.

7. Davidson, J. A., and Krysinska-Kaczmarek, M. 2007. Effects of inoculum concentration, temperature, plant age and interrupted wetness on infection of lentil (Lens culinaris) by Botrytis spp. conidia. Aust. Plant Pathol. 36:389-396.

8. Dik, A. J., and Wubben, J. P. 2004. Epidemiology of Botrytis cinerea diseases in greenhouses. Pages 319-333 in: Botrytis: Biology, Pathology and Control. Y. Elad, B. Williamson, P. Tudzynski, and N. Delen, eds. Kluwer Academic Publishers, Dordrecht, The Netherlands.

9. Droby, S., and Lichter, A. 2004. Post-harvest Botrytis infections: etiology, development and management. Pages 349-367 in: Botrytis: Biology, Pathology and Control. Y. Elad, B. Williamson, P. Tudzynski, and N. Delen, eds. Kluwer Academic Publishers, Dordrecht, The Netherlands.

10. Eden, M. A., Hill, R. A., Beresford, R., and Stewart, A. 1996. The influence of inoculum concentration, relative humidity, and temperature on infection of greenhouse tomatoes by Botrytis cinerea. Plant Pathol. 45:795-806.

11. Elad, Y. 1997. Responses of plants to infection by Botrytis cinerea and novel means involved in reducing their susceptibility to infection. Biol. Rev. 72:381-422.

12. Elad, Y. 2000. Changes in disease epidemics on greenhouse grown crops. Acta Hortic. 534:213-220.

13. Elad, Y., and Evensen, K. 1995. Physiological aspects of resistance to Botrytis cinerea. Phytopathology 85:637-643.

14. Elad, Y., Köhl, J., and Fokkema, N. J. 1994. Control of infection and sporulation of Botrytis cinerea on bean and tomato by saprophytic yeasts. Phytopathology 84:1193-1200.

15. Elad, Y., and Shtienberg, D. 1995. Botrytis cinerea in greenhouse vegetables: Chemical, cultural, physiological and biological controls and their integration. Integr. Pest Manage. Rev. 1:15-29.

16. Elad, Y., Williamson, B., Tudzynski, P., and Delen, N., eds. 2004. Botrytis: Biology, Pathology and Control. Kluwer Academic Publishers, Dordrecht, The Netherlands.

17. Elad, Y., Williamson, B., Tudzynski, P., and Delen, N. 2004. Botrytis spp. and diseases they cause in agricultural systems - an introduction. Pages 18 in: Botrytis: Biology, Pathology and Control. Y. Elad, B. Williamson, P. Tudzynski, and N. Delen, eds. Kluwer Academic Publishers, Dordrecht, The Netherlands.

18. Elad, Y., and Yunis, H. 1993. Effect of microclimate and nutrients on development of cucumber gray mold (Botrytis cinerea). Phytoparasitica 21:257-268

19. Elad, Y., Yunis, H., and Mahrer, Y. 1988. The effect of climatic conditions in polyethylene-covered structures on gray mold disease of winter cucumbers. Appl. Agric. Res. 3:243-247.

20. Elad, Y., Yunis, H., and Volpin, H. 1993. Effect of nutrition on susceptibility of cucumber, eggplant and pepper crops to Botrytis cinerea. Can. J. Bot. 71:602-608.

21. Friedrich, S., Gebelein, D., and Boyle, C. 2005. Control of Botrytis cinerea in glasshouse fuchsia by specific climate management. Eur. J. Plant Pathol. 111:249-262.

22. Guetsky, R., Shtienberg, D., Elad, Y., and Dinoor, A. 2001. Combining biocontrol agents to reduce the variability of biological control. Phytopathology 91:621-627.

23. Harrison, J. G. 1980. Effects of environmental factors on growth of lesions on field bean leaves infected by Botrytis fabae. Ann. Appl. Biol. 95:53-61.

24. Hartill, W. F. T., and Campbell, J. M. 1977. Effects of leaf maturation on development of the Sclerotinia/Botrytis complex of tobacco. N.Z. J. Agric. Res. 20:415-420.

25. Hausbeck, M. K., Pennypacker, S. P., and Stevenson, R. E. 1996. The use of forced heated air to manage Botrytis stem blight of geranium stock plants in a commercial greenhouse. Plant Dis. 80:940-943.

26. Heilbronn, J., and Harrison, J. G. 1989. Effects of bean leaf age on pathogenicity by Botrytis fabae. J. Phytopathol. 126:272-278.

27. Hobbs, E. L., and Waters, W. E. 1964. Influence of nitrogen and potassium on susceptibility of Chrysanthemum morifolium to Botrytis cinerea. Phytopathology 54:674-676.

28. Holz, G., Coertze, S., and Williamson, B. 2004. The ecology of Botrytis on plant surfaces. Pages 9-27 in: Botrytis: Biology, Pathology and Control. Y. Elad, B. Williamson, P. Tudzynski, and N. Delen, eds. Kluwer Academic Publishers, Dordrecht, The Netherlands.

29. Hyre, R. A. 1972. Effect of temperature and light on colonization and sporulation of Botrytis pathogen on geranium. Plant Dis. Rep. 56:126130 .

30. Jarvis, W. R. 1992. Managing Diseases in Greenhouse Crops. The American Phytopathological Society, St. Paul, MN.

31. Legard, D. E., Xiao, C. L., Mertely, J. C., and Chandler, C.K. 2000. Effects of plant spacing and cultivar on incidence of Botrytis fruit rot in annual strawberry. Plant Dis. 84:531-538.

32. Madden, L. V., Hughes, G., and Van den Bosch, F. 2007. The Study of Plant Disease Epidemics. The American Phytopathological Society, St. Paul, MN.

33. Mills, D. J., Coffman, C. B., Teasdale, J. R., Everts, K. L., and Anderson, J. D. 2002. Factors associated with foliar disease of staked fresh market tomatoes grown under differing bed strategies. Plant Dis. 86:356-361.

34. Morgan, W. M. 1984. The effect of night temperature and glasshouse ventilation on the incidence of Botrytis cinerea in a late-planted tomato crop. Crop Prot. 3:243-251.

35. O'Neill, T. M., Shtienberg, D., and Elad, Y. 1997. Effect of some host and microclimate factors on infection of tomato stems by Botrytis cinerea. Plant Dis. 81:36-40.

36. Saks, Y., Copel, A., and Barkai Golan, R. 1996. Improvement of harvested strawberry quality by illumination: Colour and Botrytis infection. Postharvest Biol. Technol. 8:19-27.

37. Sharabani, G., Shtienberg, D., Elad, Y., and Dinoor, A. 1999. Epidemiology of Botrytis cinerea in sweet basil and implications for disease management. Plant Dis. 83:554-560.

38. Shtienberg, D., Elad, Y., Niv, A., Nitzani, Y., and Kirshner, B. 1998. Significance of leaf infection by Botrytis cinerea in stem rotting of tomatoes grown in non-heated greenhouses. Eur. J. Plant Pathol. 104:753-763.

39. Singh, R., Sharma, R. R., and Goyal, R. K. 2007. Interactive effects of planting time and mulching on 'Chandler' strawberry (Fragaria $\times$ ananassa Duch.). Sci. Hortic. 111:344-351.

40. Sirjusingh, C., Sutton, J. C., and Tsujita, M. J. 1996. Effects of inoculum concentration and host age on infection of geranium by Botrytis cinerea. Plant Dis. 80:154-159.

41. Snell F. D., and Snell, C. T. 1949. Colorimetric Methods Analysis Including Some Turbidimetric and Nephelometric Methods. Vol. 2: Inorganic. D. Van Nostrand, Toronto. 
42. Swallow, W. H. 1984. Those overworked and off-misused mean separation procedures-Duncan's, LSD, etc. Plant Dis. 68:919-921.

43. Swartzberg, D., Kirshner, B., Elad, Y., and Granot, D. 2008. Botrytis cinerea induces senescence and is inhibited by autoregulated expression of the IPT gene. Eur. J. Plant Pathol. 120:289-297.

44. Trolinger, J. C., and Strider, D. L. 1984. Botrytis blight of Exacum affine and its control. Phytopathology 74:1181-1188.

45. Van den Berg, L., and Lentz, C. P. 1968. The effect of relative humidity and temperature on survival and growth of Botrytis cinerea and Sclerotinia sclerotiorum. Can. J. Bot. 46:1477-1481.

46. Verhoeff, K. 1968. Studies on Botrytis cinerea in tomatoes. Effect of soil nitrogen level and of methods of deleafing upon occurrence of $B$. cinerea under commercial conditions. Neth. J. Plant Pathol. 74:184-192.

47. Volpin, H., and Elad, Y. 1991. Influence of calcium nutrition on susceptibility of rose flowers to gray mold. Phytopathology 81:1390-1394.

48. Vrind, T. A. 2005. The Botrytis problem in figures. Acta Hortic. 669:99-102.
49. Wegulo, S. N., and Vilchez, M. 2007. Evaluation of lisianthus cultivars for resistance to Botrytis cinerea. Plant Dis. 91:997-1001.

50. Wolcan, S., Ronco, L., Bo, E. D., Lori, G., and Alippi, H. 1996. First report of diseases on lisianthus in Argentina. Plant Dis. 80:223.

51. Yermiyahu, U., Shamai, I., Peleg, R., Dudai, N., and Shtienberg, D. 2006. Reduction of Botrytis cinerea sporulation in sweet basil by altering the concentrations of nitrogen and calcium in the irrigation solution. Plant Pathol. 55:544-552.

52. Young, J. F. 1967. Humidity control in the laboratory using salt solutions-A review. J. Appl. Chem. 17:241-244.

53. Zhang, P. G., and Sutton, J. C. 1994. Effects of wetness duration, temperature, and light on infection of black spruce seedlings by Botrytis cinerea. Can. J. For. Res. 24:707-713.

54. Zhang, P. G., Sutton, J. C., He, B., and Hopkin, A. A. 1995. Low light intensity predisposes black spruce seedlings to infection by Botrytis cinerea. Can. J. Plant Pathol. 17:13-18. 